\title{
Global changes in dryland vegetation dynamics (1988-2008) assessed by satellite remote sensing: comparing a new passive microwave vegetation density record with reflective greenness data
}

\author{
N. Andela ${ }^{1}$, Y. Y. Liu ${ }^{2,4}$, A. I. J. M. van Dijk ${ }^{3,4}$, R. A. M. de Jeu ${ }^{1}$, and T. R. McVicar ${ }^{4}$ \\ ${ }^{1}$ Earth and Climate Cluster, Department of Earth Sciences, Faculty of Earth and Life Sciences, VU-University, Amsterdam, \\ the Netherlands \\ ${ }^{2}$ Water Research Centre, School of Civil and Environmental Engineering, University of New South Wales, Sydney, Australia \\ ${ }^{3}$ Fenner School of Environment \& Society, The Australian National University, Canberra, Australia \\ ${ }^{4}$ CSIRO Land and Water, GPO Box 1666, Canberra, 2601, ACT, Australia
}

Correspondence to: N. Andela (n.andela@vu.nl)

Received: 12 April 2013 - Published in Biogeosciences Discuss.: 28 May 2013

Revised: 19 August 2013 - Accepted: 12 September 2013 - Published: 24 October 2013

\begin{abstract}
Drylands, covering nearly $30 \%$ of the global land surface, are characterized by high climate variability and sensitivity to land management. Here, two satellite-observed vegetation products were used to study the long-term (19882008) vegetation changes of global drylands: the widely used reflective-based Normalized Difference Vegetation Index (NDVI) and the recently developed passive-microwavebased Vegetation Optical Depth (VOD). The NDVI is sensitive to the chlorophyll concentrations in the canopy and the canopy cover fraction, while the VOD is sensitive to vegetation water content of both leafy and woody components. Therefore it can be expected that using both products helps to better characterize vegetation dynamics, particularly over regions with mixed herbaceous and woody vegetation. Linear regression analysis was performed between antecedent precipitation and observed NDVI and VOD independently to distinguish the contribution of climatic and non-climatic drivers in vegetation variations. Where possible, the contributions of fire, grazing, agriculture and $\mathrm{CO}_{2}$ level to vegetation trends were assessed. The results suggest that NDVI is more sensitive to fluctuations in herbaceous vegetation, which primarily uses shallow soil water, whereas VOD is more sensitive to woody vegetation, which additionally can exploit deeper water stores. Globally, evidence is found for woody encroachment over drylands. In the arid drylands, woody encroachment appears to be at the expense of herbaceous vegetation and a global driver is interpreted. Trends
\end{abstract}

in semi-arid drylands vary widely between regions, suggesting that local rather than global drivers caused most of the vegetation response. In savannas, besides precipitation, fire regime plays an important role in shaping trends. Our results demonstrate that NDVI and VOD provide complementary information and allow new insights into dryland vegetation dynamics.

\section{Introduction}

Drylands cover nearly $30 \%$ of the global land surface, they are characterized by high climate variability and are sensitive to land use practice (Tietjen et al., 2010). Over the last decades, many dryland ecosystems have faced increased pressure from human demands and climate change (Asner et al., 2004; Dore, 2005; Liu et al., 2013a). Here we define arid drylands as all areas that have a ratio of longterm mean annual precipitation to mean annual potential

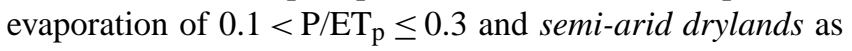
$0.3<\mathrm{P} / \mathrm{ET}_{\mathrm{p}} \leq 0.7$. Globally the primary drivers of vegetation dynamics in drylands include: (i) climate (Herrmann et al., 2005; Bai et al., 2008); (ii) fire regime (Bond and Keeley, 2005; Archibald et al., 2010); (iii) grazing (Asner et al., 2004; Liu et al., 2013b); (iv) agriculture (Piao et al., 2003; Jeyaseelan et al., 2007); and (v) atmospheric $\mathrm{CO}_{2}$ concentrations (Bond and Midgley, 2012; Donohue et al., 2013). Of these, 
fire, grazing and agriculture can be considered the main disturbance processes that affect large-scale vegetation trends in drylands. Other factors, e.g., nitrogen deposition and changes in growing season length (Bai et al., 2008) may also play an important role locally. Changes in the five primary drivers are expected to result in differential responses of woody cover (i.e., woody encroachment or decline) and herbaceous cover (Archer et al., 1995; Van Auken, 2000; Bond et al., 2003; Asner et al., 2004).

Although supporting evidence has been found that each of the five primary drivers can result in responses of dryland vegetation cover, simultaneous changes of the five primary drivers and interactions among them and interaction with ecosystem processes make it difficult to attribute change to any single driver (Bond and Midgley, 2012). Using remote sensing data the evidence of climate impacting vegetation dynamics has been studied at regional (Evans and Geerken, 2004; Herrmann et al., 2005; Wessels et al., 2007), continental (Donohue et al., 2009) and global scales (Nemani et al., 2003). To date, the impact of grazing and fire have not been included in global studies of dryland vegetation dynamics (e.g., Nemani et al., 2003; Fensholt et al., 2012; de Jong et al., 2011). Remote sensing data on global fire regimes are available, with many improved products becoming available since the launch of the first Moderate Resolution Imaging Spectroradiometer (MODIS) in 1999 (Kaufman et al., 1998). Studies of fire-induced vegetation change are mainly performed regionally (e.g., Flannigan et al., 2009; Archibald et al., 2010; Heisler et al., 2003) with notable exceptions focusing on longer timescales (Bowman et al., 2009; Bond et al., 2005). Vegetation indices have been widely used as indicators for advances in agricultural practice (e.g., irrigation and fertilization) and annual crop yields (e.g., Tottrup and Rasmussen, 2004), while land cover maps provide information on the spatial extent of agriculture. Several studies provide field evidence of the impact of grazing (Van Auken, 2000; Asner et al., 2003) and rising $\mathrm{CO}_{2}$ levels (McMahon et al., 2010; Buitenwerf et al., 2011) on vegetation cover; however, these studies are regional, presumably to avoid problems of complexity and data availability. As a consequence, at a global scale the relative importance of climate, fire, grazing, agriculture and $\mathrm{CO}_{2}$ on vegetation dynamics is still actively debated and so far unresolved (Archer et al., 1995; Asner et al., 2004; Bond and Keeley, 2005; Bond et al., 2005; Fensham et al., 2005; Sankaran et al., 2005; Buitenwerf et al., 2011; Lehmann et al., 2011; Bond and Midgley, 2012).

Satellite remote sensing is a powerful tool to globally study both woody encroachment and desertification over multiple decades, complementing local to regional field evidence and process studies. For global studies, the Normalized Difference Vegetation Index (NDVI) is the most widely used spectral vegetation index and is based on a ratio of red and near-infrared reflectance (Rouse et al., 1974; Tucker, 1979; Beck et al., 2011). NDVI has been used as an indicator of vegetation productivity (Tucker et al., 1985;
McVicar and Jupp, 1998); and is related to leaf area index (LAI; Wang et al., 2005), canopy cover fraction and the fraction of absorbed photosynthetically active radiation (fPAR; Asrar et al., 1984; Carlson and Ripley, 1997; Lu et al., 2003). Complementary to the NDVI, a recently developed data set is Vegetation Optical Depth (VOD). VOD describes the transparency of vegetation in the microwave domain and is mostly sensitive to vegetation water content (Kirdiashev et al., 1979). Owe et al. (2001) developed the Land Parameter Retrieval Model (LPRM) to derive VOD from low-frequency passive microwave observations. This model was further improved by Meesters et al. (2005) and has been applied to a series of passive microwave sensors (Owe et al., 2008). VOD is sensitive to vegetation water content in both the woody and leafy vegetation components, and provides a measure of aboveground biomass (Liu et al., 2011a).

Separately, both reflective and microwave products have been used to study vegetation dynamics. Pettorelli et al. (2005) review ecological studies that used NDVI to examine climate- and human-induced vegetation change (e.g., Evans and Geerken, 2004; Herrmann et al., 2005; Wessels et al., 2007), global vegetation trends (e.g., de Jong et al., 2011; Fensholt et al., 2012) and land degradation (e.g., Bai et al., 2008). Long VOD time series were only recently developed, and have been used to study vegetation phenology (Shi et al., 2008; Jones et al., 2011, 2012) and to show the impact of El Niño-Southern Oscillation on Australian vegetation cover (Liu et al., 2007). Global trends in VOD were shown to correspond to changes in precipitation, livestock (e.g., overgrazing), crop production, deforestation and fires (Liu et al., 2013a, b).

To date, only an introductory assessment of potential insights from a combined interpretation of NDVI and VOD cotrends has been performed (Liu et al., 2011a). While many regions had similar co-trends regional differences were illustrating that VOD provides new information for mixed woody-herbaceous land cover types. Due to the characteristics of both products, differential responses to changes in land cover are expected (Shi et al., 2008). Compared to VOD, NDVI saturates at relatively low biomass and is therefore most sensitive to vegetation covering the largest surface (Tucker, 1979). As a consequence, temporal correlation between NDVI and VOD is high for grass and croplands but lower for high biomass vegetation types where NDVI saturates (Liu et al., 2011a). Grasses are the main source of large interannual variation in NDVI for savanna ecosystems (Archibald and Scholes, 2007; Roderick et al., 1999b; Lu et al., 2003; Donohue et al., 2009). VOD has a greater penetration capacity and is more sensitive to changes in woody vegetation (Liu et al., 2011a; Shi et al., 2008). The relationship between NDVI and VOD is further explored in the background theory section.

This paper uses the two complementary remote sensing data sets and analyzes their trends across the global drylands. In particular, we address the following questions: 
1. How do NDVI and VOD complement each other and what do combined trends tell us about vegetation dynamics?

2. What component of temporal dryland vegetation dynamics is explained by precipitation?

3. What are the remaining trends in both vegetation indices, and how are they related to the other primary drivers (fire, grazing, agriculture and $\mathrm{CO}_{2}$ )?

Differences between NDVI and VOD are explored and their trends and co-trends are interpreted ecologically over the global drylands. A model is developed to estimate the dryland vegetation responses that can be explained by precipitation variation. Residual trends (i.e., the observed minus model-explained trends) and their potential drivers are discussed and attributed where possible, by comparison with independent data sets (e.g., burned area and grazing) and information from previous studies.

\section{Background theory}

A conceptual framework is required to relate temporal patterns and trends in NDVI and VOD to vegetation characteristics. For NDVI, the reflectance observations from which it is derived are often described by a linear mixture of the constituent surface reflectance components (cf. Roberts et al., 1998):

$\rho=f_{\mathrm{o}} \rho_{\mathrm{o}}+\left(1-f_{\mathrm{o}}\right)\left(f_{\mathrm{u}} \rho_{\mathrm{u}}+f_{\mathrm{s}} \rho_{\mathrm{s}}\right)$,

where $\rho$ is the wavelength reflectance and $f$ the fraction canopy cover, with subscripts denoting overstory (o), understory (u) and soil surface (s). This is a somewhat simplified approach, as light reflecting from one component can affect reflectance of another component by multiple scattering and transmittance (Roberts et al. , 1993). Homogeneous vegetation cover is assumed such that the overstory will obscure some part of the understory, and it is assumed that the NDVI observations are representative for nadir measurements such that $f$ equates to projected canopy cover. Here it is assumed that the overstory and understory can be assumed equal to the (woody) persistent and (herbaceous) recurrent vegetation components (cf. Roderick et al., 1999b; Lu et al., 2003; Donohue et al., 2009). NDVI is calculated as a reflectance difference index and therefore, using Eq. (1) it can be shown that NDVI will respond to surface component mixing ratios in a slightly non-linear manner, although NDVI still converges to end member NDVI values when these dominate overall reflectance (Asner, 1998). NDVI per unit canopy area for recurrent vegetation tends to exceed that of persistent vegetation, with recurrent vegetation having shorter-lived and "greener" (i.e., higher chlorophyll density) leaves (Reich et al., 1997, 2003). As a result, all else being equal, an increase in NDVI can be explained by an increase in total canopy cover or a relative increase in recurrent vegetation canopy cover, or both.

VOD (denoted $\tau$ ) can be interpreted as being linearly related to total aboveground biomass (AGB) water content, i.e., the sum of water in woody and non-woody vegetation (Jackson et al., 1982; Wigneron et al., 1993):

$\tau=\tau_{o}+\tau_{u}=c_{\tau}\left(\theta_{o} m_{o}+\theta_{u} m_{u}\right)$,

where $\theta$ is vegetation water content, $m$ the $\mathrm{AGB}$, and $c_{\tau}$ the constant of proportionality. $\theta$ will normally be greater for herbaceous vegetation than for woody vegetation (Roderick et al., 1999a, 2000), therefore increases in VOD can mean an increase in total AGB, an increase of the fraction of herbaceous vegetation AGB, or both.

Finally, the relationship between NDVI and VOD is influenced by the connection between AGB $(m)$ and canopy cover $(f)$. This relationship can be presented by considering the commonly used light extinction equation (Monsi and Saeki, $2005)$ that relates $f$ to leaf area index $(\Lambda)$ :

$f=1-\exp (-\kappa \Lambda)=1-\exp \left(-\kappa \alpha_{\text {SLA }} f_{\text {leaf }} m\right)=1-\exp \left(-c_{\Lambda} m\right)$,

where $\kappa$ is the extinction coefficient, $\alpha_{\mathrm{SLA}}$ the specific leaf area (i.e., area per unit leaf mass), and $f_{\text {leaf }}$ the fraction of leaf biomass in total AGB. While $\kappa$ depends on leaf orientation and clumping, $f_{\text {leaf }}$ and $\alpha_{\mathrm{SLA}}$ will be greater for non-woody vegetation than for woody vegetation. Overall, total AGB remaining unchanged, the sensitivity of NDVI to a relative increase in the herbaceous AGB is expected to be considerably greater than the sensitivity of VOD. VOD, being sensitive to AGB water content, is expected to be more sensitive to a relative increase in woody vegetation. Per unit mass the tree foliage will have a somewhat higher relative water content than the woody parts, but because woody biomass typically represents $90 \%$ or more of total aboveground biomass (Northup et al., 2005, and references therein) it still contains most of the water (Sternberg and Shoshany, 2001). By using the trend information from the different vegetation data sets the above considerations lead to the following four expectations:

1. a long-term increase in both NDVI and VOD signifies an increase in the relative fraction of herbaceous AGB and/or an increase in total AGB;

2. a long-term increase in NDVI combined with a decrease in VOD signifies an increase in the relative fraction of herbaceous AGB;

3. a long-term decrease in NDVI and an increase in VOD signifies an increase in the relative fraction of woody AGB; and

4. a long-term decrease in both NDVI and VOD signifies a decrease in the relative fraction of herbaceous AGB and/or a decrease in total AGB. 


\section{Materials}

To study global long-term dryland vegetation dynamics, both NDVI and VOD data sets were used for their overlapping period 1988-2008. Both vegetation indices are dimensionless and here we use a $0.25^{\circ}$ spatial and monthly temporal resolution.

\subsection{Normalized Difference Vegetation Index (NDVI)}

The NDVI data are Global Inventory Modeling and Mapping Studies 3rd generation (GIMMS3g) derived from the Advanced Very High Resolution Radiometer (AVHRR) sensor on board the NOAA series of satellites (i.e., NOAA 7 , 9, 11, 14, 16 and 17; Tucker et al., 2005). Although datasets are merged from several sensors and corrections were performed (Tucker et al., 2005), they do not affect the calculated trends (Fensholt and Proud, 2012). These data were resampled from $1 / 12^{\circ}$ to $0.25^{\circ}$ spatial resolution and from twice to once monthly temporal resolution by simple averaging. Data were available between 1981-2010. Recently Beck et al. (2011) showed that of four AVHRR processing chains tested, GIMMS was best able to track trends in 1424 Landsat image pairs.

\subsection{Vegetation Optical Depth (VOD)}

Liu et al. (2011a) developed a harmonized VOD data set for 1988-2008 by merging VOD retrievals from SSM/I (Special Sensor Microwave Imager, 1988-2007), TMI (the microwave instrument onboard the Tropical Rainfall Measuring Mission satellite, 1998-2008) and AMSR-E (the Advanced Microwave Scanning Radiometer - Earth Observing System, 2002-2008) using the LPRM algorithm. This harmonized data set preserves the relative dynamics (e.g., seasonality and interannual variations) of the original products (Liu et al., 2011b) and is able to capture long-term changes in total aboveground vegetation water content and biomass over various land cover types globally (Liu et al., 2013a). Because of enhanced sensor characteristics (particularly the longer wavelength), the accuracy of VOD retrievals from AMSR$\mathrm{E}$ is expected to be better than those from TMI and SSM/I. A comprehensive evaluation study by Liu et al. (2013a) demonstrated that the errors associated to sensor changes in the harmonized VOD data set are small, however. The harmonized data set captured long-term changes in total aboveground vegetation water content and biomass over different land cover types without sensor artefacts. The VOD data should be interpreted with caution over sandy deserts, open water and under the frost conditions (de Jeu, 2003; Jones et al., 2011; Gouweleeuw et al., 2012).

\subsection{Additional data sets}

\subsubsection{Precipitation}

Precipitation data (monthly; 1901-2009) produced by the University of East Anglia Climatic Research Unit (CRU Time Series version 3.1) were available at a $0.5^{\circ}$ resolution (Jones and Harris, 2008). For analysis it was assumed that within this grid cell precipitation was homogeneously distributed and data was resampled to a $0.25^{\circ}$ resolution (Koenig , 2002).

\subsubsection{Land cover}

The MODIS Land Cover Type Yearly Climate Modeling Grid (MCD12C1; 2005; $0.05^{\circ}$ resolution), land cover map was used here (NASA, 2008). Data was resampled to a $0.25^{\circ}$ resolution using the land cover with the highest frequency in each grid cell. The land cover types follow the University of Maryland (UMD) classification scheme (Hansen et al., 2000). For our analysis some land cover classes were merged to assist interpretation (i.e., urban and built-up, barren or sparsely vegetated, and unclassified + fill were here merged into "barren or sparsely vegetated"; all types of forest into "forest"; and closed and open shrublands into "shrublands").

\subsubsection{Fire}

Monthly burned area data was available based on MODIS Terra satellite imagery MCD64A1; $500 \mathrm{~m}$ resolution; November 2000 onwards (Giglio et al., 2009). Data was rescaled to a monthly $0.25^{\circ}$ resolution by calculating the mean burned area per $0.25^{\circ}$ grid cell.

\subsubsection{Livestock}

Livestock density was available from the Food and Agriculture Organization's (FAO) Gridded Livestock of the World data (http://www.fao.org/AG/againfo/resources/ en/glw/GLW_dens.html; Robinson et al., 2007) and was expressed in Tropical Livestock Units (TLU) per $\mathrm{km}^{2}$ $(1 \mathrm{TLU}=250 \mathrm{~kg}$ live weight, cattle $=0.7 \mathrm{TLU}$, sheep and goats $=0.1 \mathrm{TLU}$; Jahnke, 1982).

\section{Methods}

\subsection{Relationship between NDVI and VOD}

To illustrate the theoretical relations between NDVI and VOD (Sect. 2), we calculated global mean values and standard deviation for both vegetation indices. To provide more insight, we calculated annual mean values and range (between maximum and minimum) and compared seasonal patterns of three southern African land cover types with increasing woody cover: (i) grasslands, (ii) savannas and (iii) woody savannas. In addition to earlier explorations on the 
relationship between NDVI and VOD (Liu et al., 2011a; Shi et al., 2008), the results of these analysis were used to verify the four expectations of Sect. 2, regarding the co-trends between NDVI and VOD. Trends in NDVI and VOD were analyzed separately (Sects. 4.2 and 4.3), but co-trends (NDVI and VOD) were also interpreted using our theoretical framework.

\subsection{Response of vegetation index anomalies to antecedent precipitation anomalies}

Following Evans and Geerken (2004) and Herrmann et al. (2005), linear regression models between antecedent precipitation and each vegetation index were developed for each grid cell. These regression models were used to estimate the long-term vegetation trends expected due to precipitation patterns alone. Estimated vegetation trends were calculated in three steps. Firstly, anomalies were calculated both for precipitation and the vegetation products (NDVI and VOD). Second, the antecedent precipitation index (API) was calculated, here defined as the optimal correlating precipitation running mean (PRM) as judged from Spearman's ranked correlation coefficient $\left(R_{\mathrm{S}}\right)$ over 1- to 60-month averaging periods. The $\operatorname{API}(x, y, t)$ was calculated for each grid cell $(x, y)$ and month $(t)$ using

$\operatorname{API}(x, y, t)=\frac{\sum_{t-(T(x, y)-1)}^{t} d^{\prime}(x, y, t)}{T(x, y)}$,

where $T$ is the averaging period in months for antecedent precipitation that leads to the highest $R_{\mathrm{S}}$ between the PRM and the vegetation anomalies and $d^{\prime}$ is the precipitation anomaly. The estimated vegetation variation was calculated as a linear function of API:

estimated $(x, y, t)=a_{1}(x, y) \cdot \operatorname{API}(x, y, t)+a_{2}(x, y)$.

For each grid cell the coefficients $a_{1}$ and $a_{2}$ were determined by least squared differences between the API and vegetation anomaly time series. Similar approaches were used by Evans and Geerken (2004), Herrmann et al. (2005) and Wessels et al. (2007) for NDVI, who also assumed (as we do) that if estimated vegetation variation based on precipitation variation was removed from observed vegetation anomalies, the residual trends are largely independent of precipitation. Here we develop models based on precipitation and vegetation anomalies (rather than the original vegetation indices) as all trends are present in the anomalies, and not in the seasonal pattern. So a model optimized for anomalies will give a better estimation of trends in the vegetation indices caused by precipitation. Although direct correlation between precipitation and vegetation indices will be higher than correlation between vegetation index and precipitation anomalies, a model based on the original vegetation indices and precipitation would be more suitable to study the effect of precipitation on seasonal rather than interannual vegetation dynamics.
However, to facilitate comparison with previous studies, the analysis was also repeated using the original vegetation indices rather than anomalies (cf. Herrmann et al., 2005).

\subsection{Global dryland vegetation trends}

After calculating the estimated index anomalies, trends were calculated for the observed, estimated and residual vegetation index. The residual trend was calculated as the trend in the observed minus estimated vegetation anomaly and represents the component of the signal that could not be directly attributed to precipitation variations. A conventional nonparametric Mann-Kendall trend test was used to determine areas of significant monotonic trends (cf. de Jong et al., 2011; Fensholt et al., 2012; Liu et al., 2013a). The non-parametric Theil-Sen estimator of slope is insensitive to outliers and was used to calculate linear trends (Sen, 1968; Theil, 1950).

Climate and land cover affect NDVI and VOD dynamics and will likely cause them to respond differently to the primary drivers of dryland vegetation dynamics. Hence, to stratify our results, we used global maps of land cover (Fig. 1a) and $\mathrm{P} / \mathrm{ET}_{\mathrm{p}}$ classes; referred to as humidity classes hereafter (Fig. 1b). Global maps of livestock density, burned area, recent trends in burned area, and ecosystem characteristics of land cover and humidity were used to interpret results. Only static livestock density and land cover data were available, but these could in some cases be combined with regional studies to interpret the influence on vegetation dynamics. It was assumed that globally consistent trends not explained by climate, fire, grazing and agricultural developments are caused by increasing atmospheric $\mathrm{CO}_{2}$ concentrations (Bond et al., 2003; Donohue et al., 2013). Impact of fire on vegetation indices was further explored studying time series of NDVI, VOD and burned area for grassland, savanna and woody savanna in southern Africa.

Grid cells with less than $40 \%$ valid data (i.e., 100 or less of the 252-month series) in either vegetation data set were not included in this analysis. NDVI cannot be used over snow and ice (Brown et al., 2006), while VOD is sensitive to frost conditions (see Sect. 3.2; Liu et al., 2011a), hence seasonally recurrent data gaps exist in both products during winter. The threshold of $40 \%$ valid data was chosen to include most drylands at high latitudes/elevations. Data gaps were ignored in trend calculations yet are considered in their interpretation.

\section{Results}

\subsection{Relationship between NDVI and VOD}

Globally, for the arid drylands, mean VOD values were generally lower than NDVI, with increasing humidity and biomass VOD increased faster than NDVI (Fig. 2a and b). Most notable examples of large differences between NDVI and VOD were forests and agricultural regions of the temperate northern hemisphere drylands. NDVI generally showed 
Table 1. Percentage of global drylands with significant $(p<0.05)$ correlation between API and the two vegetation indices for land cover and humidity classes. The average humidity $\left(\mathrm{P} / \mathrm{ET}_{\mathrm{p}}\right)$ for each land cover class is shown in brackets with the land cover classes ordered in increasing humidity. $1 \%$ represents $\approx 750$ grid cells $\left(0.25^{\circ}\right.$ resolution), and abbreviations of land cover classes are explained in the legend of Fig. 1a.

\begin{tabular}{lrrr|rrrr}
\hline \multicolumn{3}{c}{ Land cover } & & \multicolumn{4}{c}{ Humidity } \\
\hline Class & $\begin{array}{r}\text { Total } \\
{[\%]}\end{array}$ & $\begin{array}{r}\text { NDVI } \\
{[\%]}\end{array}$ & $\begin{array}{r}\text { VOD } \\
{[\%]}\end{array}$ & Class & $\begin{array}{r}\text { Total } \\
{[\%]}\end{array}$ & $\begin{array}{r}\text { NDVI } \\
{[\%]}\end{array}$ & $\begin{array}{r}\text { VOD } \\
{[\%]}\end{array}$ \\
\hline B/SV $(0.15)$ & 4.3 & 3.6 & 3.3 & $0.1-0.3$ & 38.2 & 35.0 & 35.9 \\
Sh $(0.21)$ & 21.3 & 19.9 & 20.1 & $0.3-0.5$ & 29.8 & 26.5 & 26.3 \\
Gr $(0.33)$ & 27.4 & 23.8 & 24.4 & $0.5-0.7$ & 32.0 & 19.7 & 18.6 \\
Sa $(0.45)$ & 11.4 & 9.9 & 10.5 & & & & \\
Cr $(0.51)$ & 17.9 & 14.6 & 13.2 & & & & \\
WSa $(0.53)$ & 8.3 & 6.1 & 6.4 & & & & \\
Fo $(0.59)$ & 9.5 & 3.4 & 2.9 & & & & \\
\hline Total & 100.0 & 81.2 & 80.7 & Total & 100.0 & 81.2 & 80.7 \\
\hline
\end{tabular}

(a) Dominant land cover type

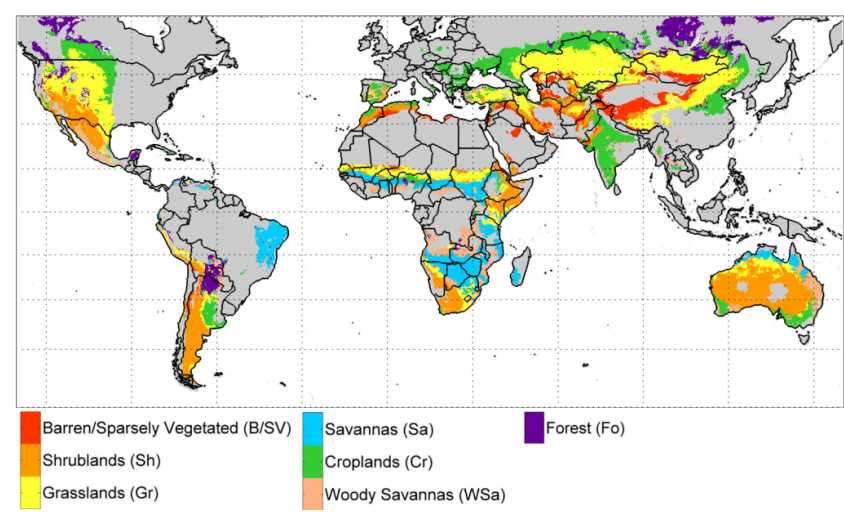

(b) Humidity classes $\left(\mathrm{P} / \mathrm{ET}_{p}\right)[-]$

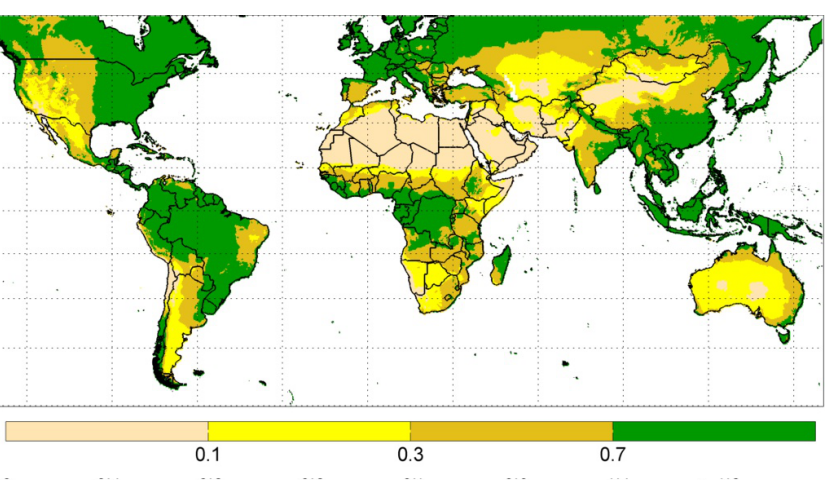

Fig. 1. Characterization of ecosystems in terms of land cover and humidity. (a) MODIS dominant land cover type, herein referred to as land cover; and (b) humidity classes, based on $50 \mathrm{yr}$ average (1950-2000) precipitation (P) data (Hijmans et al., 2005) and potential evaporation $\left(\mathrm{ET}_{\mathrm{p}}\right)$ data (Zomer et al., 2008). All maps in this paper (except for Fig. $3 \mathrm{~d}$ ) are projected in the Miller cylindrical projection $\left(60^{\circ} \mathrm{N}-60^{\circ} \mathrm{S}\right.$, $\left.130^{\circ} \mathrm{W}-160^{\circ} \mathrm{E}\right)$. Terrestrial areas that are not drylands $(0.1<$ humidity $\leq 0.7)$ are from now on masked grey in all figures and are excluded from analysis, and oceans are masked (white) in all figures.

higher standard deviations than VOD, especially for drylands that face cold winters (Fig. 2c and d). Regional exceptions were observed, with standard deviation of VOD being larger for some savanna regions in northern and southern Africa and Australia. More detail was provided by studying three land cover types of southern Africa (study areas are shown in Fig. 3d). With increasing woody cover, VOD increased faster than NDVI (Fig. 3a, b and c). The annual average VOD for grassland was 0.41 and for woody savanna this increased to 0.70 (i.e., a 0.29 increase). In contrast, the annual average NDVI only increased by 0.19 (i.e., from 0.43 for grassland to 0.62 for woody savanna). The NDVI range (annual maximum minus minimum) exceeded the VOD range for all three land cover types (Fig. 3a, b and c).

\subsection{Response of vegetation index anomalies to antecedent precipitation anomalies}

The strongest correlation $\left(R_{\mathrm{S}}\right)$ between vegetation anomalies and antecedent precipitation index (API) were observed over arid drylands $\left(0.1<\mathrm{P} / \mathrm{ET}_{\mathrm{p}} \leq 0.3\right.$; Fig. $4 \mathrm{a}$ and $\left.\mathrm{c}\right)$. While NDVI and VOD showed similar spatial patterns, VOD showed higher correlation coefficients, suggesting that VOD reacts stronger to interannual precipitation variability in drylands than NDVI. In regions with low or insignificant correlations between vegetation and API, factors other than precipitation are likely to determine interannual vegetation variability and/or variability was minimal over the study period. While in general the strongest correlation was found between VOD and API, the total area of significant correlation was similar for both vegetation indices (Table 1). 
(a) NDVI mean [-]

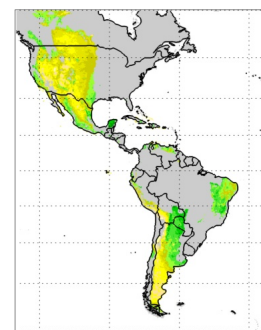

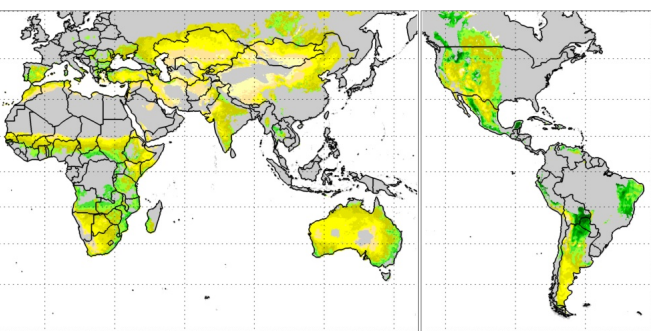

(b) VOD mean [-]

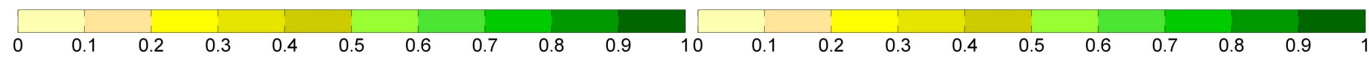

(c) NDVI standard deviation [-]

(d) VOD standard deviation [-]
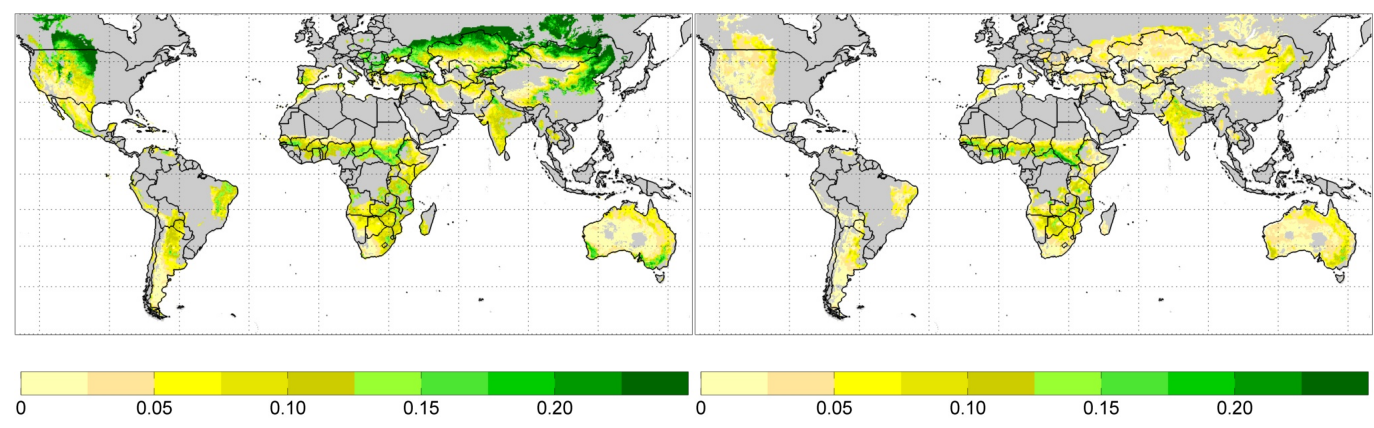

Fig. 2. Mean values and standard deviation of vegetation indices (1988-2008). (a) Mean NDVI; (b) mean VOD; (c) standard deviation of NDVI; and (d) standard deviation of VOD.

Averaging periods (denoted $T$ in the methods; Fig. $4 \mathrm{~b}$ and d) are related to the capacity of vegetation to use antecedent precipitation and the lead time of interannual variation in precipitation followed by a vegetation response. NDVI generally has shorter averaging periods than VOD (cf. Fig. 4b with d). To facilitate comparison with other studies, model results based on original vegetation indices and precipitation are shown in the annex material (Fig. A1). In general, observed correlation was higher, and averaging periods were shorter for the model based on original vegetation indices and precipitation (Fig. A1) than when compared to the model based on anomalies used here (Fig. 4, see Sect. 4.2). Figure 5 shows box plots of the data in Fig. 4, stratified by land cover and humidity classes. Both NDVI and VOD showed longest averaging periods for areas dominated by woody vegetation and croplands, shorter periods were observed for grasslands and savannas.

Figure 6 shows an example of estimated and observed anomalies in NDVI and VOD for two $5^{\circ} \times 5^{\circ}$ regions (Fig. 3d): (i) eastern Australia (25-30 $\left.\mathrm{S}, 145-150^{\circ} \mathrm{E}\right)$; and (ii) southern Africa $\left(25-30^{\circ} \mathrm{S}, 20-25^{\circ} \mathrm{E}\right)$. Modeled NDVI is based on shorter averaging periods, because the signal showed little interannual variation. VOD, on the other hand, is usually based on longer averaging periods and therefore follows the interannual variation in precipitation, being less sensitive to small intra-annual variability.

\subsection{Global dryland vegetation trends}

For some regions, observed annual trends in NDVI and VOD (1988-2008) showed similar trends: e.g., India, North America, eastern Australia, and northern African savannas (Fig. 7a and $b$ ). Other areas showed contrasting trends between the data sets: e.g., southern Africa, northern Australia, Argentina and central Asia. While observed trends in NDVI and VOD differ considerably, the estimated trends in NDVI and VOD were relatively similar and strong decreasing trends were found in southeastern Australia and Mongolia, while increasing trends were found in most of Africa and northern Australia (Fig. 7c and d). Figure 7e and $\mathrm{f}$ show residual trends, calculated as observed anomalies minus estimated vegetation anomalies. For the NDVI (Fig. 7e) some trends persisted (e.g., positive trends over most of India and Spain, and negative trends over southern Russia and Kazakhstan). In other cases, if observed and estimated trends had the opposite direction (i.e., one is positive and the other negative) this resulted in enhanced residual trends (e.g., Argentina, arid northern Africa, southern Africa and northern Australia in the case of NDVI; compare Fig. 7a, c and e). If observed and estimated trends had the same direction this resulted in smaller residual NDVI trends (e.g., Mongolian steppe and semi-arid drylands of northern Africa), or trends tended to zero (e.g., southern India and northern China). Finally, in some regions new NDVI trends emerged (southeastern 
(a) Grassland

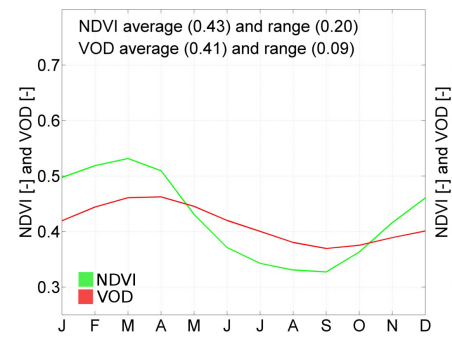

(c) Woody savanna

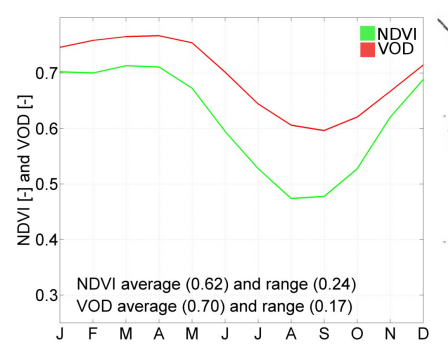

(b) Savanna

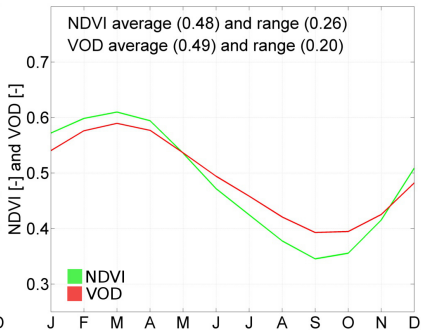

(d) Study areas

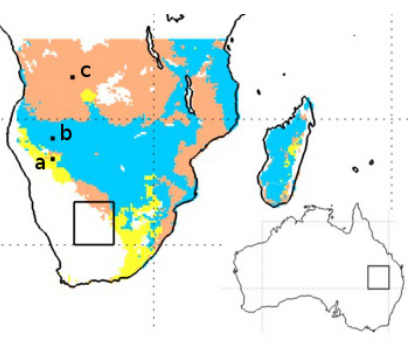

Fig. 3. Long-term (1988-2008) average monthly NDVI and VOD signals for three common land cover classes of southern Africa (5$\left.35^{\circ} \mathrm{S}, 10-50^{\circ} \mathrm{E}\right)$ : (a) grassland $\left(7330.25^{\circ}\right.$ resolution grid cells), (b) savanna (4041 $0.25^{\circ}$ resolution grid cells), and (c) woody savanna (3826 $0.25^{\circ}$ resolution grid cells). The annual average and range of both vegetation indices are reported on each sub-plot. (d) shows an overview of the study areas used in Figs. 3, 6 and 10. Australia is shown at half the scale of southern Africa. The three regions, based on land cover, used in (a-c) are shown in yellow (grassland), blue (savanna) and pink (woody savanna).

Australia and southwest Western Australia). Observed and estimated trends in VOD generally had the same direction, resulting in smaller residual trends (e.g., northern Australia, Sahel, southern Africa and southern Argentina; compare Fig. 7b, d and f). Although there were also regions with trends in observed VOD, and no corresponding trends in estimated vegetation anomalies (e.g., east Africa and northern India). Figure $8 \mathrm{a}-\mathrm{c}$ shows the co-trends between NDVI and VOD using the four categories of our conceptual framework, and their corresponding ecological interpretation is shown in Fig. 8d.

Median observed trends in NDVI were increasing for savanna and croplands, and decreasing for the other land cover classes (Fig. 9a). For VOD decreasing median observed trends were found in forested drylands, while increasing median trends were found for all other land cover classes (Fig. 9a). Over arid drylands the median VOD trend was increasing while NDVI showed mostly decreasing trends, for more humid drylands NDVI and VOD trends were more similar and closer to zero (Fig. 9d). Savannas and shrublands showed a small increase in estimated median NDVI and VOD (Fig. 9b), indicating that part of the change in median vegetation index response is explained by trends in precipitation. There were no particular humidity classes that showed a large change in estimated median vegetation response, indicating that median changes in precipitation were close to zero for each humidity class (Fig. 9e). In the residual trends (i.e., observed minus estimated) similar but smaller median trends remained, both for NDVI and VOD (Fig. 9c and f).

Vegetation trends (Fig. 7), are expected to be related to trends in precipitation (Fig. 10a) and trends in annual burned area (Fig. 10b). Most global drylands experienced stable or increasing precipitation amounts during 1988-2008; notable exceptions are southeast Australia, northern India, the Mongolian steppe and northern China (Fig. 10a). Trends in annual burned area declined for northern Africa and increased in most of southern Africa (2001-2011; Fig. 10b). Southern America showed a mixed pattern of increased and declined trends of annual burned area, while trends of annual burned area over most of Australia have been stable or declined. The relationship between burned area and vegetation indices was further analyzed using three study areas with different land cover in southern Africa (locations are shown in Fig. 3d). For grasslands, annual burned area is relatively low and no obvious relationship between vegetation indices and burned area is present (Fig. 11a). In savannas, secondary to precipitation, both NDVI and VOD are related to interannual variation in burned area (Fig. 11b; compare 2006 and 2008 with the other years). For woody savannas, increased annual burned area together with relatively low annual minimum NDVI values were observed in 2004 and 2007-2009, but interannual variation was much smaller.

\section{Discussion}

\subsection{Relationship between NDVI and VOD}

Our conceptual framework resulted in four expectations corresponding to the four categories of Fig. 8d. In addition to exploring the relation between NDVI and VOD theoretically, we illustrate these expectations by comparing global distribution of mean and standard deviation of both vegetation indices. Following Liu et al. (2011a), we found that VOD showed stronger increase than NDVI, moving from low to high biomass regions (Figs. 2a, b and 3). Standard deviations of the vegetation indices were mostly influenced by seasonal fluctuations in greenness and AGB, driven by precipitation and/or temperature. While NDVI is more sensitive to seasonal greening in regions dominated by herbaceous vegetation (Archibald and Scholes, 2007; Donohue et al., 2009, Fig. 3), for southern Africa the seasonal biomass fluctuations seem to be better captured by the VOD signal. Ovington et al. (1963) show that seasonal AGB variation (mostly caused by herbaceous vegetation and tree leaves) for savanna vegetation is about three times larger than for grassland. This corresponds to a 2.2 times increase in VOD range from grasslands to savannas. By comparison, the NDVI range only increased 1.3 times (Fig. 3a and b). As the exact physical relationships 
Spearman's rank correlation coefficient $\left(R_{s}\right)$

Averaging period [months]
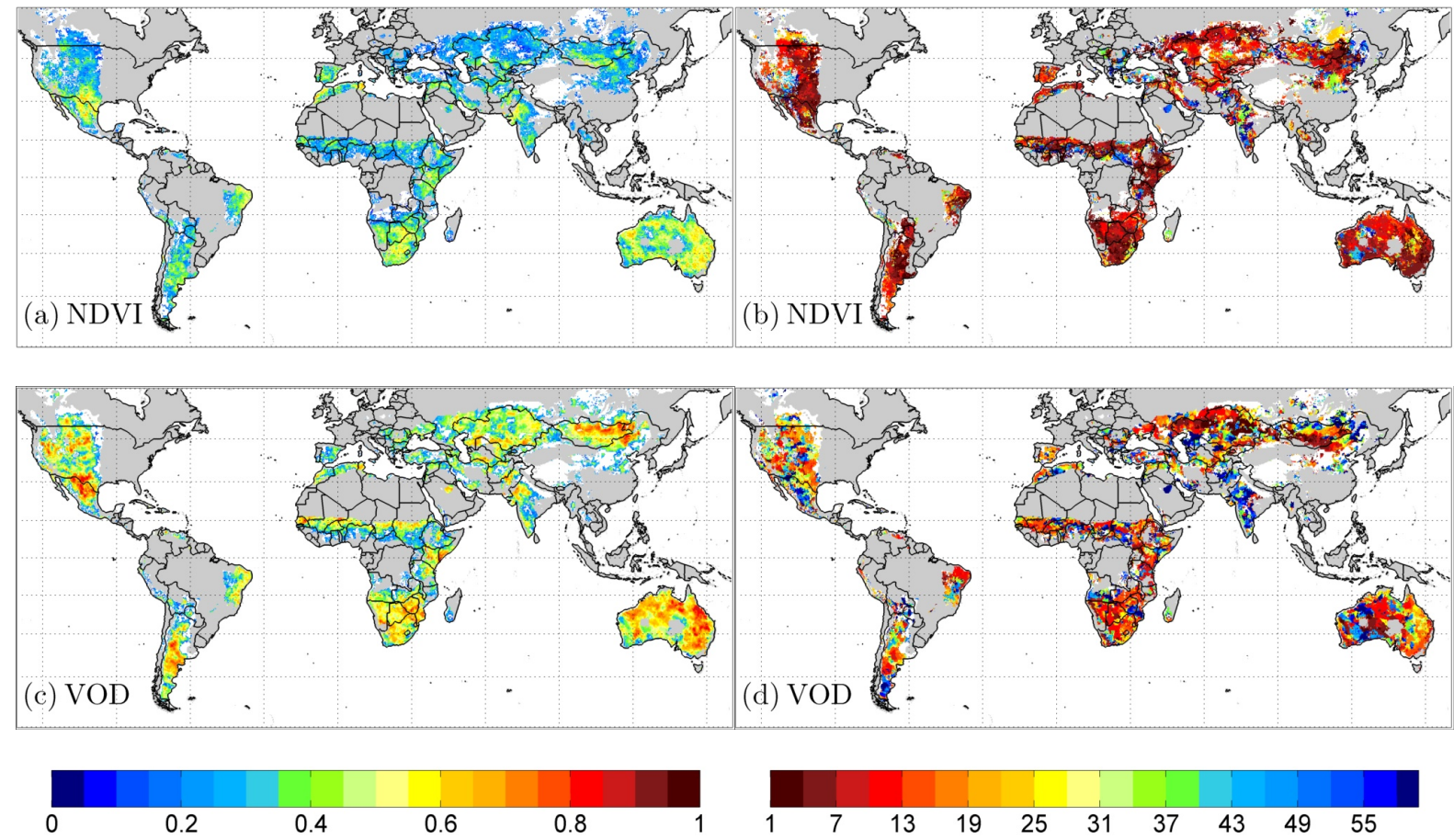

Fig. 4. Spearman's rank correlation coefficient $\left(R_{\mathrm{S}}\right)$ and averaging periods for the two vegetation indices. For the NDVI (a) is the $R_{\mathrm{S}}$ between API and the NDVI anomaly and (b) is the averaging period for antecedent precipitation that leads to the highest $R_{\mathrm{S}}$ between PRM and the vegetation anomalies (denoted as $T$ in the methods), (c) and (d) are as (a) and (b) except for the VOD. Grid cells without significant correlation $(p<0.05)$, with over $60 \%$ missing values, or with a negative correlation coefficients are masked (white).
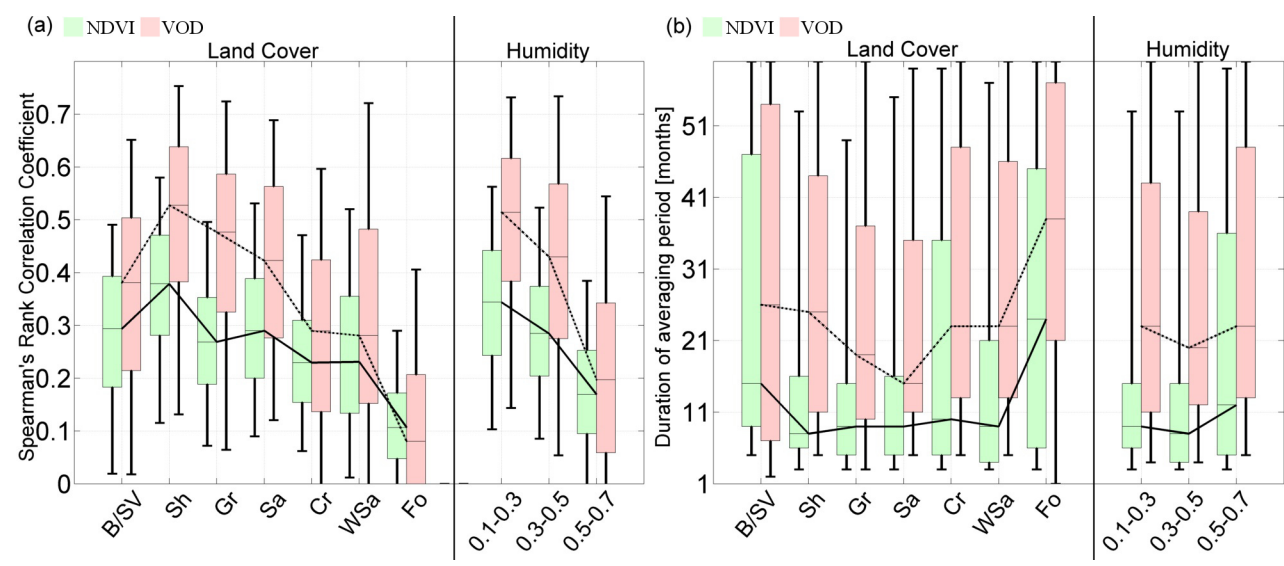

Fig. 5. Box plots showing the distribution of $R_{\mathrm{S}}$ and averaging periods for the two vegetation indices. (a) Distribution of $R_{\mathrm{S}}$ between observed vegetation anomalies and API for NDVI and VOD, stratified by: (left) land cover classes and (right) humidity classes; and (b) the distribution of the duration of averaging period for antecedent precipitation that leads to strongest correlation between the PRM and observed vegetation anomalies, stratified by: (left) land cover classes and (right) humidity classes. Solid lines indicate the NDVI medians and dash-dot lines the VOD medians. The maximum and minimum extents of the colored boxes indicate 25 th and 75 th percentiles and whiskers represent the 5 th and 95th percentiles. Grid cells with over $60 \%$ missing values are not included in this figure, and grid cells without significant correlation $(p>0.05)$ in Fig. 4 are not included in Fig. 5b. Abbreviations of land cover classes are explained in the legend of Fig. 1a.

between NDVI and VOD are currently being resolved, we limit our theoretical framework (Sect. 2; Fig. 8) to contrasting trends in NDVI and VOD, comparing directions rather than the magnitudes of trends. Furthermore, the conceptual framework applies to both temporal and spatial vegetation dynamics. For example, an increase in both NDVI and VOD 
Eastern Australia
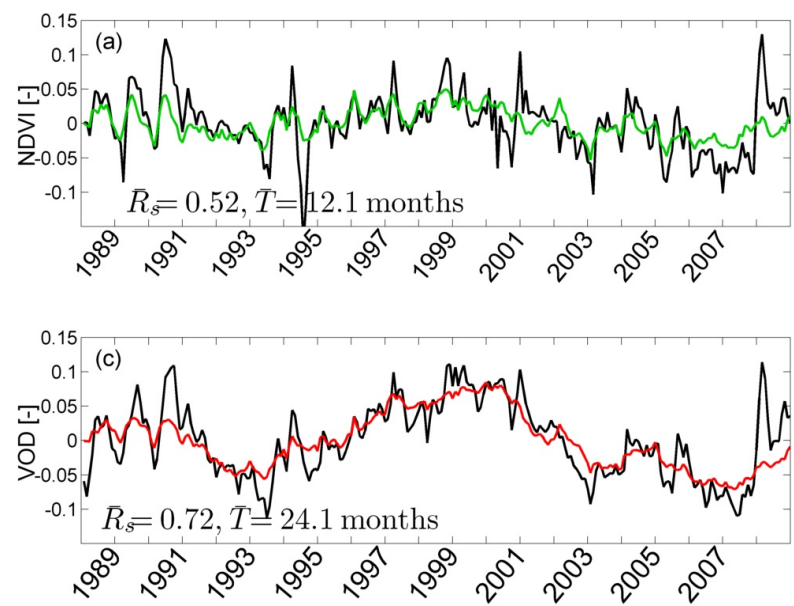

Southern Africa
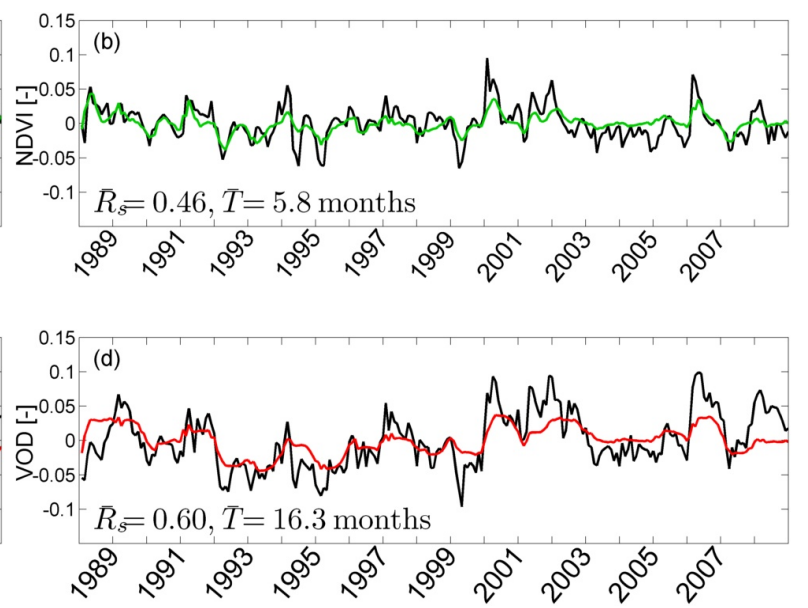

Fig. 6. Time series of estimated and observed vegetation anomalies. Estimated NDVI (green) and observed NDVI (black) vegetation anomalies are shown for regions in (a) eastern Australia $\left(25-30^{\circ} \mathrm{S}, 145-150^{\circ} \mathrm{E}\right)$ and (b) southern Africa $\left(25-30^{\circ} \mathrm{S}, 20-25^{\circ} \mathrm{E}\right)$, (c) and (d) are as (a) and (b) except for the estimated VOD (red) and observed VOD (black) vegetation anomalies. The average Spearman's ranked correlation coefficient $\left(R_{\mathrm{S}}\right)$ and averaging period $(T)$ of all $0.25^{\circ}$ resolution grid cells in each $5^{\circ}$ region are listed in each sub-plot. Locations of both $5^{\circ}$ regions are shown in Fig. $3 \mathrm{~d}$.

signifies an increase in the relative fraction of herbaceous AGB and/or an increase in the total AGB; this can be caused both by increased growing season length and/or by actual changes in vegetation density.

\subsection{Response of vegetation index anomalies to antecedent precipitation anomalies}

As expected, arid drylands showed the strongest correlation between the vegetation index anomalies and API (i.e., median $R_{\mathrm{S}}$ NDVI $>0.3$, median $R_{\mathrm{S}}$ VOD $>0.5$; see Fig. 5 ). Nemani et al. (2003) mapped these areas as being water limited, and for higher latitudes, water- and temperature limited. Correlation is less strong than found when analyzing the original indices (Fig. A1; Herrmann et al., 2005) because seasonal vegetation-precipitation responses are not included. In semiarid drylands, regions that have a strong seasonal precipitation response do not necessarily show a strong interannual response (compare Fig. 4a and c with Fig. A1). This can be explained by a seasonal abundance of water in which variation in precipitation does not affect vegetation, followed by a dry season in which the vegetation is unable to use antecedent precipitation.

Following previous studies (Evans and Geerken, 2004; Herrmann et al., 2005; Nemani et al., 2003; Wessels et al., 2007; Donohue et al., 2009), we also found that not all interannual variation can be explained by precipitation alone. Precipitation-driven estimated trends in NDVI and VOD largely agree with trends in soil moisture reported by Dorigo et al. (2012). VOD generally shows longer averaging periods than NDVI, this is because they are sensitive to different components of vegetation cover (Fig. 3a-c); NDVI is more sensitive to changes in the shallow rooted herbaceous understory (Archibald and Scholes, 2007), and VOD more sensitive to changes in the woody overstory, which can also utilize moisture from deeper soil and groundwater stores (Rossatto et al., 2012; House et al., 2003). Clear geographical patterns are present in the NDVI and VOD averaging periods (see Fig. 4b and d), suggesting that physical landscape (including landform and soil type), affecting water holding capacity, likely contributes. The stronger correlations between VOD and API are attributed to the larger interannual variation in the VOD data set and caused by interannual precipitation variations (Fig. 6). Archibald and Scholes (2007) reported similar findings, and concluded that plants that access deeper water and have carbohydrate reserves may show a phenology that is quite different from surrounding areas with grass cover that depend on shallow soil moisture for their growth. It appears that similar conclusions may be drawn for interannual variation.

\subsection{Global dryland vegetation trends}

The relationship between NDVI and VOD trends (Fig. 8) provides new insights in the relative performance of herbaceous and woody vegetation components in global drylands. Woody encroachment into grassland or savannas has been observed across the globe, including Argentina (e.g., Adamoli et al., 1990), Africa (e.g., Vegten, 1984; Oldeland et al., 2010) and Australia (Fensham et al., 2005, cf. review by Archer et al., 2001). Although satellite observations of NDVI and VOD confirm our theoretical framework, future validation studies, comparing satellite observations with local to regional studies, would help to improve 


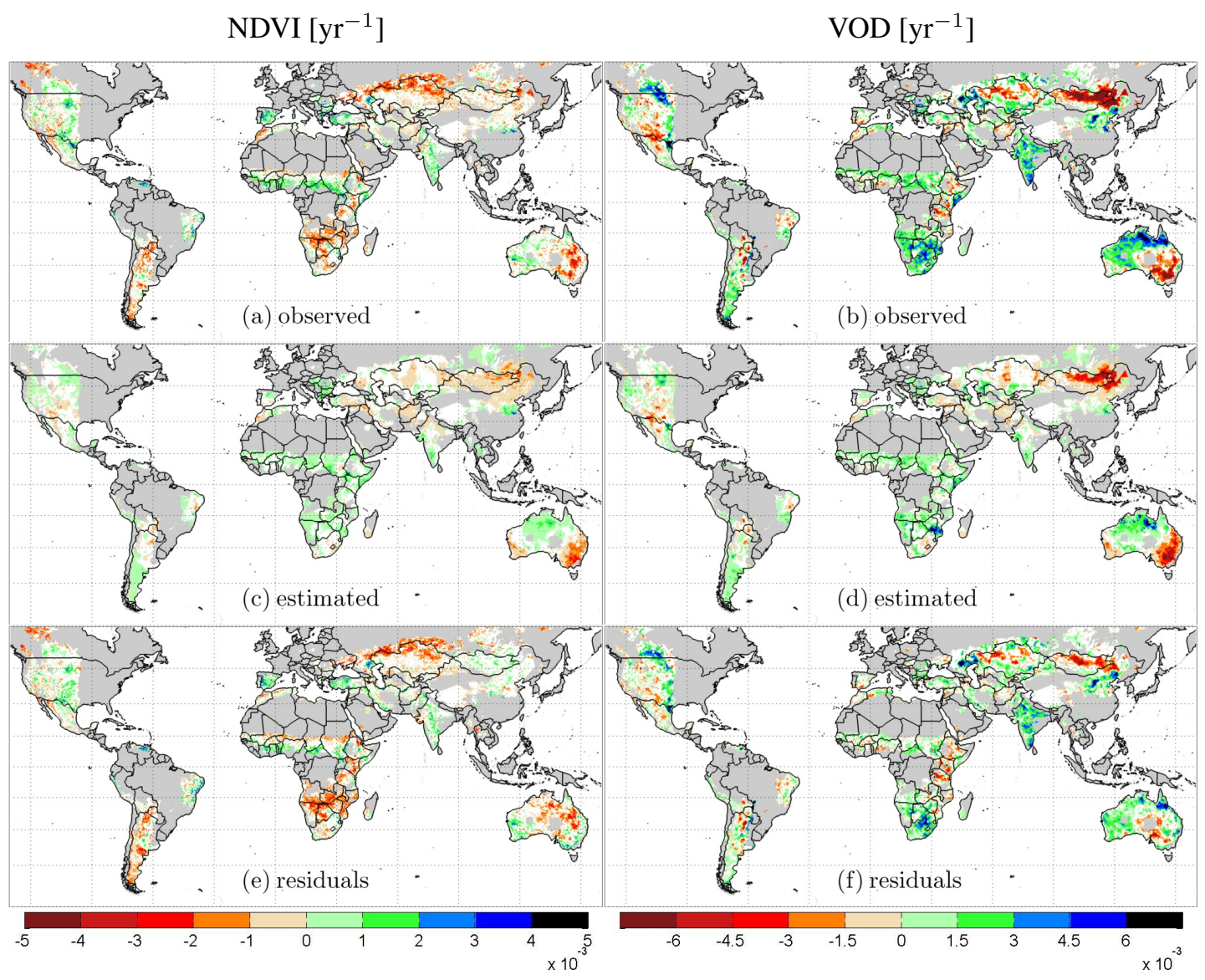

Fig. 7. Linear trends (1988-2008) of the observed, estimated and residual for both vegetation indices: (a) and (b) are the NDVI and VOD observed trends, (c) and (d) are the NDVI and VOD estimated trends, and (e) and (f) are the NDVI and VOD residual trends. Grid cells with over $60 \%$ missing values or without significant trends $(p>0.05)$ are masked (white).

(a) Observed

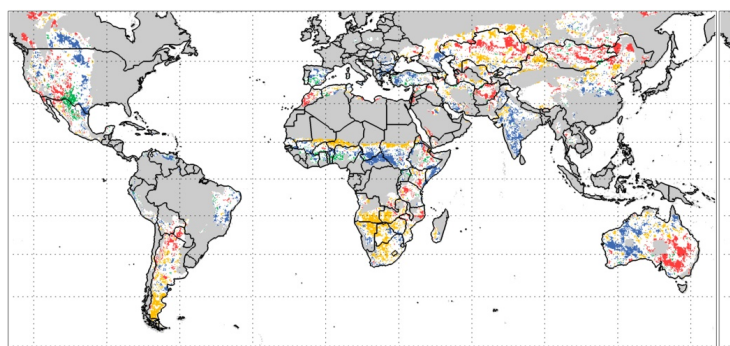

(c) Residual

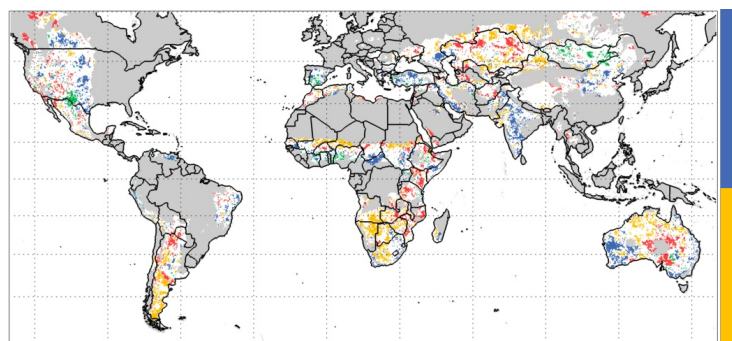

(b) Estimated

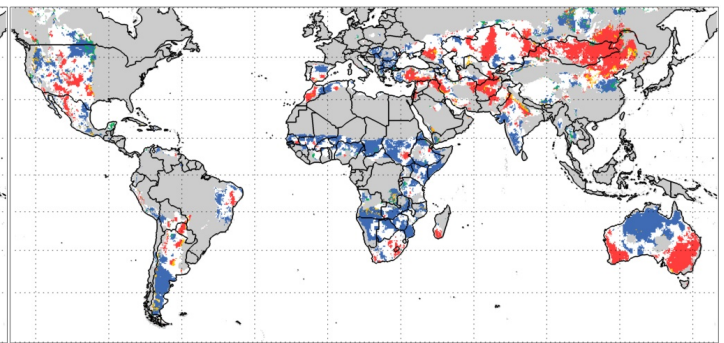

(d) Ecological interpretation

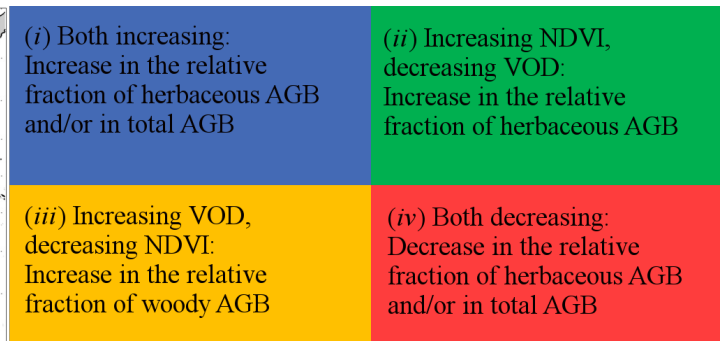

Fig. 8. Co-relationship of NDVI and VOD trends stratified into four classes: (i) both increasing; (ii) increasing NDVI and decreasing VOD; (iii) increasing VOD and decreasing NDVI; and (iv) both decreasing. (a) is the observed trends, (b) the estimated trends, and (c) the residual trends. Only grid cells with significant trends ( $p<0.05$ ) and less than $60 \%$ missing values in both products are shown. (d) shows the ecological interpretation, based on the four expectations of the background theory section. 
regional interpretation and confidence. Vegetation trends of the world's arid drylands and semi-arid drylands are discussed in turn. Overall, the world's drylands show a decrease in NDVI and an increase in VOD (Fig. 9d).

\subsubsection{Arid drylands $\left(0.1<\mathrm{P}_{\mathrm{E}} \mathrm{ET}_{\mathrm{p}} \leq 0.3\right)$}

The world's arid drylands are mainly covered by shrublands $(48.2 \%)$ and grasslands $(31.3 \%)$. Trends over bare or sparsely vegetated areas $(10.6 \%)$ need to be treated with care due to the limitations of both vegetation indices over those regions (see Sect. 3; Tucker et al., 2005; Brown et al., 2006). Many arid drylands experienced unchanged or increasing annual precipitation (Fig. 10b), and median estimated trends in both vegetation indices were close to zero (Fig. 9e). NDVI median trend for arid drylands was negative while VOD median trend was positive (Fig. 9e). Both the relatively constant or increasing VOD trends and most negative trends in NDVI remain after precipitation-induced variation is accounted for (Fig. 7e and f). This results in many regions showing opposite trends in NDVI and VOD (Fig. 8; e.g., arid drylands of Argentina, southern Africa, northern Africa and Australia). In those regions, it seems that woody encroachment takes place at the expense of the herbaceous understory. Woody encroachment has been attributed to climate (Fensham et al., 2005), fire regime (Sankey et al., 2012), grazing (Asner et al., 2004) and $\mathrm{CO}_{2}$ fertilization (Buitenwerf et al., 2011).

Clear trends in the NDVI and VOD residuals indicate that next to precipitation, other drivers also play a role (Fig. 7e and $\mathrm{f}$ ). A possible explanation for residual trends could be changing fire regimes (Fig. 10b) through its impact on competitiveness of the herbaceous and woody vegetation components (Sankey et al., 2012). Bowman et al. (2009) showed that annual burned area is highest in areas of intermediate primary production, limited by a lack of dry periods towards the tropics and limited by a lack of fuel towards dry areas (Fig. 10d). Primary production is the main limitation on annual burned area in these drier regions (Archibald et al., 2009) and increasing precipitation and/or $\mathrm{CO}_{2}$ concentrations (Donohue et al., 2013) can increase net primary production and hence increase annual burned area in arid drylands. This results in a system of highly variable biomass production, followed by infrequent fires (Fig. 11a). Recent trends (2000-2011) in annual burned area do not show increases in most arid drylands and showed declines in northern Australia and the Sahel (Fig. 10b). This, combined with an average annual burned area of below $10 \%$ (Fig. 10d), seems to make fire an unlikely driver of globally observed changes.

Decreasing NDVI trends have been interpreted as a proxy for land degradation (Wessels et al., 2007; Bai et al., 2008) which might be caused by grazing. Grazing has also been associated with woody encroachment (e.g., Asner et al., 2004). Although grazing might cause contradicting trends between NDVI and VOD in some regions (e.g., arid parts of northern Africa) similar trends are observed in regions of limited or no grazing by domestic livestock (e.g., compare Figs. 10c and 8 for arid drylands of Argentina and Australia). The spatial patterns and scale at which trends occur suggest that grazing by domestic livestock is not the main driver in these cases, impact of grazing by non-domesticated animals was not included here, as no information was available.

Sankaran et al. (2005) suggest that woody vegetation receiving less than $350 \mathrm{~mm}$ annual precipitation is largely constrained by water availability. Rising atmospheric $\mathrm{CO}_{2}$ concentrations affects water use efficiency and photosynthetic rates (Donohue et al., 2013; Franks et al., 2013; Keenan et al., 2013) as well as light and nutrient efficiency (Drake et al., 1997; Farquhar, 1997). $\mathrm{CO}_{2}$ is reported to enhance the relative performance of woody $\mathrm{C} 3$ species over the $\mathrm{C} 4$ grasses that dominate tropical savannas (Bond and Midgley, 2012; Higgins and Scheiter, 2012). Once woody plants are established in savannas, they are likely to limit the growth of herbaceous plants through water uptake and shading (Breshears, 2006).

Increases in extreme air temperatures and changes in growing season duration can also explain some of the observed vegetation trends (Allen et al., 2010). Changing duration of rainy seasons can impact the relative performance of different species: a shorter but more intense wet season is likely to result in decreasing herbaceous understory (NDVI) during dry seasons, while deep rooted vegetation suffers less, having access to deeper water resources and therefore being more sensitive to long-term water availability (Fig. 5; Archibald and Scholes, 2007). Evidence for shortening growing seasons is found for arid drylands of northern Africa (de Jong et al., 2011). Finally, increased air temperatures can result in higher evaporation rates and during the dry season result in a competitive advantage of deep rooted species over shallow rooted species (Tietjen et al., 2010). Although air temperature is increasing over many drylands globally, decreasing trends are also observed in some regions, as temperature tends to be strongly related to precipitation through the effect of cloud cover on solar irradiation. Additionally, decreases in wind speed ("wind stilling"), and changes in other meteorological variables governing the evaporative process, also alter the evaporative regime (McVicar et al., 2012). Following Higgins and Scheiter (2012), we suggest that the effects of changing evaporation rates in drylands are less important than the effects of increasing atmospheric $\mathrm{CO}_{2}$ concentrations. Given that patterns in the residual trends are found in most global arid drylands, all experiencing very different fire and grazing conditions (compare Fig. 7e and f with Fig. 10c and d), a global driver such as $\mathrm{CO}_{2}$ fertilization appears more plausible.

\subsubsection{Semi-arid drylands $\left(0.3<\mathrm{P}_{\mathrm{ET}} \leq \mathbf{0 . 7}\right)$}

The world's semi-arid drylands mainly contain croplands $(26.4 \%)$, grasslands $(25.0 \%)$, savannas $(15.9 \%)$, forest $(15.2 \%)$ and woody savannas $(12.4 \%)$. The distribution of 

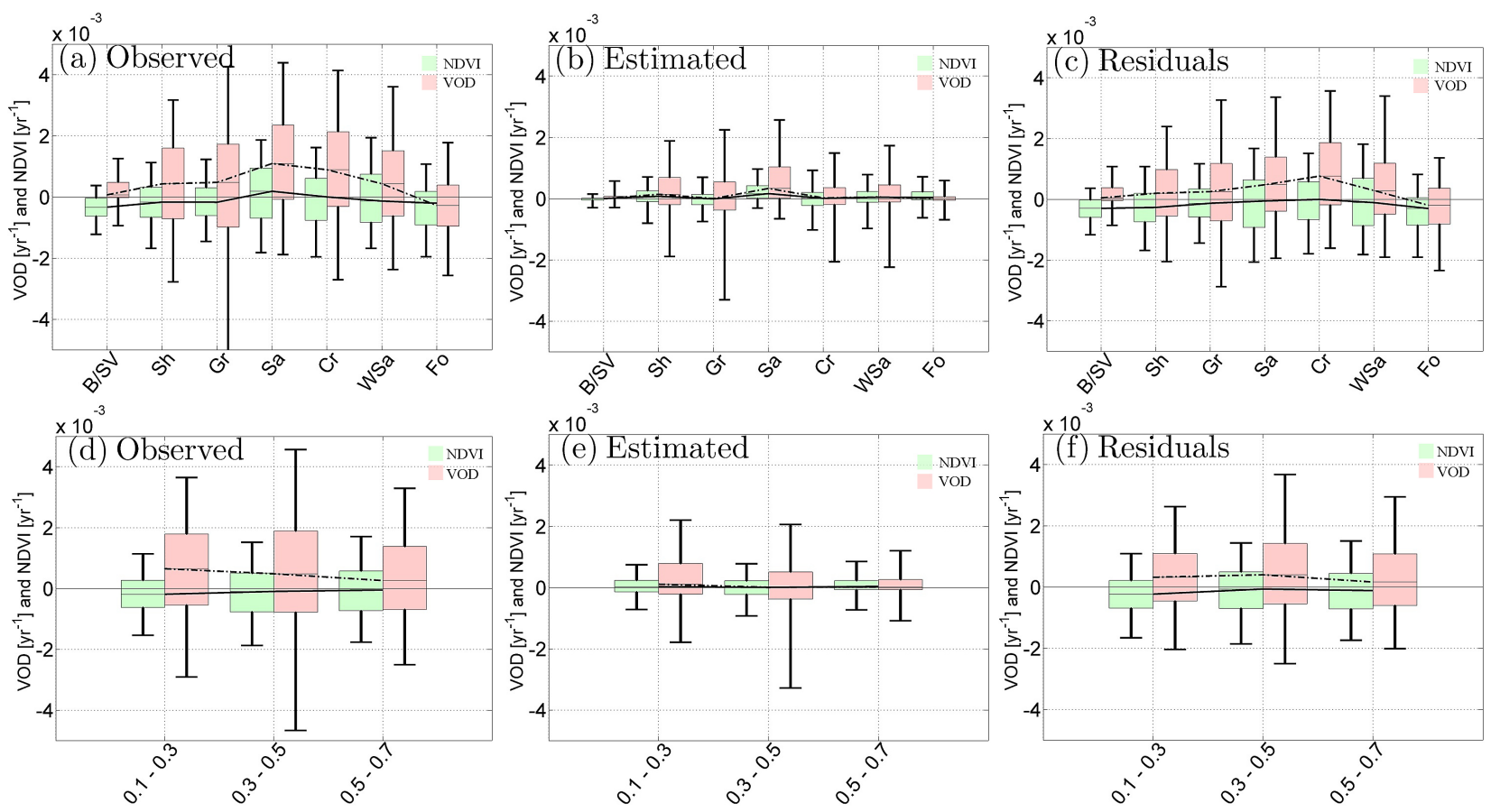

Fig. 9. Box plots of the distribution of observed, estimated and residual linear trends for both vegetation indices. Observed trends stratified by the (a) land cover and (d) humidity classes, estimated trends stratified by the (b) land cover and (e) humidity classes, and the residual trends stratified by the (c) land cover and (f) humidity classes. Solid lines indicate the NDVI medians and dash-dot lines the VOD medians. The maximum and minimum extents of the colored boxes indicate 25 th and 75 th percentiles and whiskers represent the 5th and 95th percentiles. Grid cells with over $60 \%$ missing values are not included in this figure. Abbreviations of land cover classes are explained in the legend of Fig. 1a.

trends in vegetation indices differs between humidity classes and land cover classes (Fig. 9). The median trend in NDVI is around zero for semi-arid drylands, showing positive trends over savannas and croplands and negative median trends for other land cover classes. VOD shows positive median trends for all land cover classes except forest (see Fig. 9a and d). In most semi-arid areas, where savanna grasslands dominate, resources are available to support forests which are suppressed by frequent fire (Bond and Keeley, 2005). Fire is thought to be the next most important driver of vegetation variation in savannas after precipitation (Sankaran et al., 2005).

Although northern and southern African semi-arid drylands experience similar increasing trends in precipitation (Fig. 10a), the changes in the vegetation indices are very different. In southern Africa (i.e., south of $5^{\circ} \mathrm{S}$ ), NDVI trends are declining, while VOD trends are increasing- likely caused by an increase in the relative fraction of woody AGB. Northern African savannas (in contrast with the grasslands in adjacent arid drylands), show increasing trends in NDVI, along with increasing trends (in most regions) for VOD; interpreted as an increase in the relative fraction of herbaceous AGB and/or increase in total AGB. The increasing trend in the northern African grasslands and savannas is widely discussed in literature and has been explained as a result of recovery after drought (1983-1985 being the driest years; Anyamba and Tucker, 2005) and improved land management (e.g., irrigation, and soil and water conservation; Herrmann et al., 2005). Strong trends in NDVI occur in semi-arid areas with large annual burned area (compare Fig. 7e with Fig. 10d). Northern African savannas, with recent declines in annual burned area (Fig. 10b), showed increasing NDVI values (Fig. 7e). Widespread grazing (Fig. 10c) and associated fire suppression may explain decreasing annual burned area in northern Africa between 2001 and 2011 (Fig. 10b; Archibald et al., 2010). Southern African regions, with recent increases in annual burned area, showed declining NDVI trends. We found that annual variation in burned area especially affects NDVI and VOD minimum values (Fig. 11). Human land use practice is also thought to be an important driver of annual burned area (Archibald et al., 2009). The effect of fire on vegetation indices is most profound in African and Australian savannas and woody savannas, where annual burned area typically ranges from 20 to $80 \%$ (Fig. 10d). Given the high percentage of area burnt each year in many African savannas and woody savannas (Fig. 11), it seems feasible that changing fire regimes, affecting annual minimum values of NDVI, cause the observed trend in NDVI.

Outside the African savannas and woody savannas, the residual trends in NDVI are not easily attributed to changes 
(a) Precipitation trend $\left[\mathrm{mm} \times \mathrm{yr}^{-2}\right]$

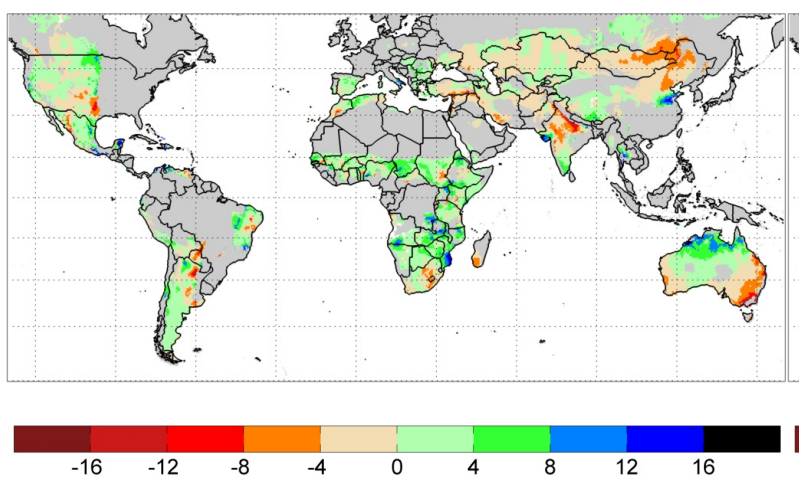

(c) Livestock density [TLU $\times \mathrm{km}^{-2}$ ]
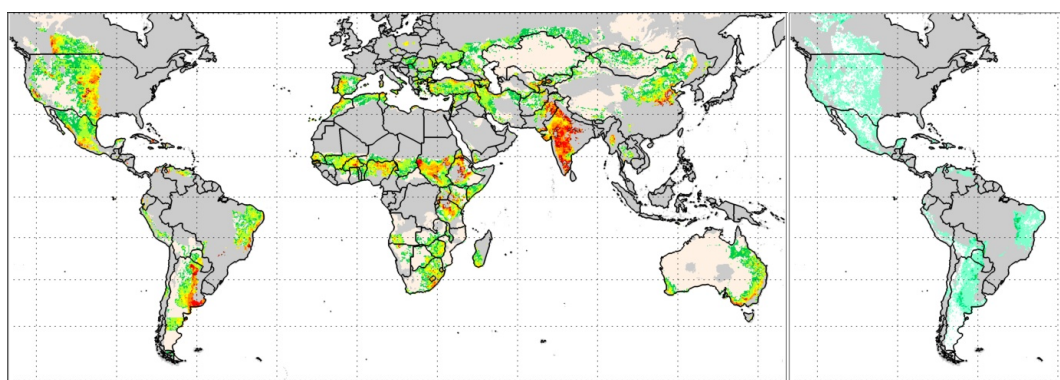

(d) Burned area $\left[\% \times \mathrm{yr}^{-1}\right]$

(b) Burned area trend $\left[\% \times \mathrm{yr}^{-2}\right.$ per $0.25^{\circ}$ region]
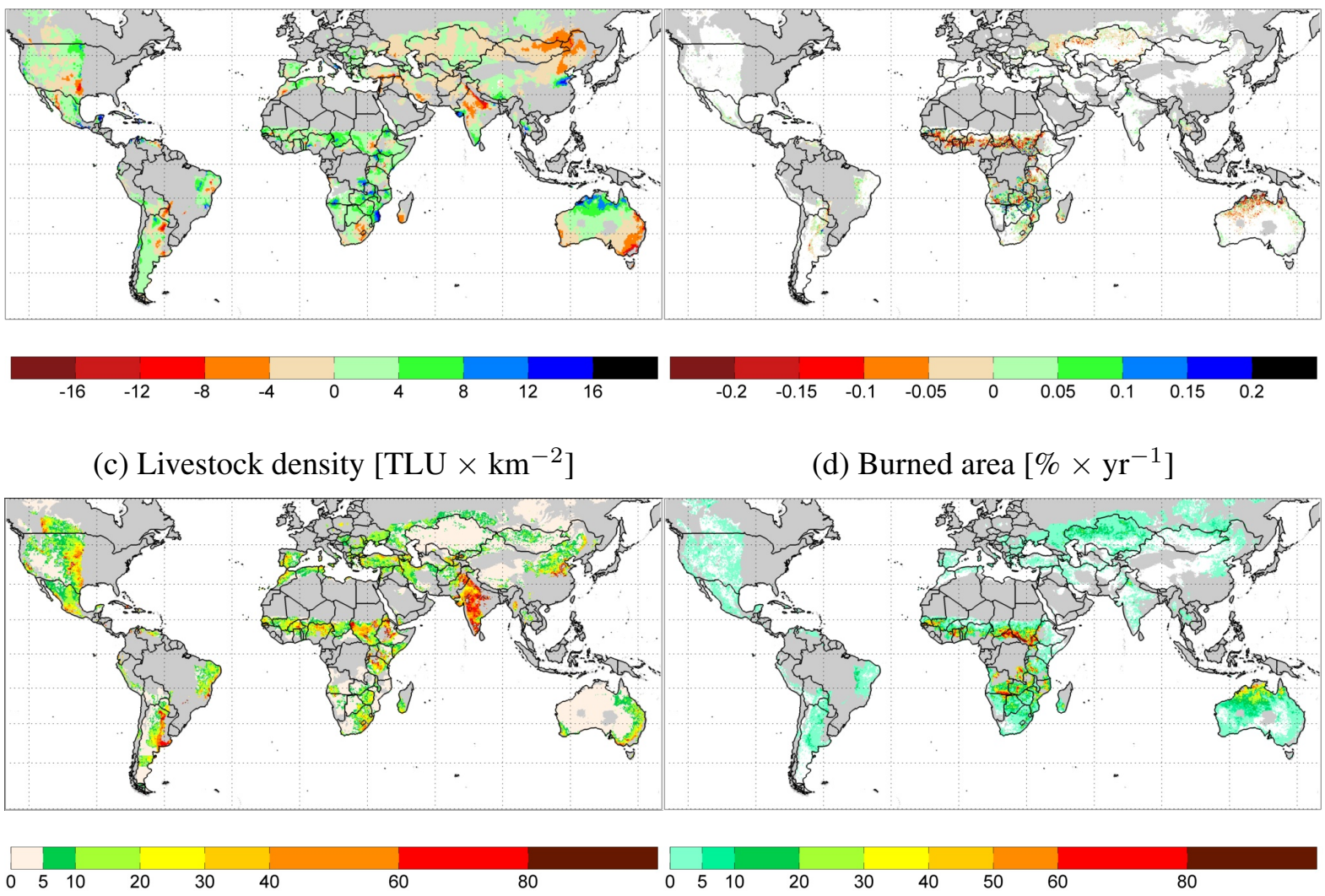

\begin{tabular}{llllllll}
\hline 0 & 5 & 10 & 20 & 30 & 40 & 50 & 60
\end{tabular}

80

Fig. 10. Data sets used for interpretation of vegetation dynamics: (a) linear trend in annual mean precipitation (1988-2008), (b) linear trend in annual mean burned area (2001-2011), (c) livestock density, and (d) mean annual burned area (2001-2011). Due to MODIS data limitations the burned area trends are calculated from 2001-2011. Trends in burned area were only calculated for grid cells with burned area in at least 6 out of $11 \mathrm{yr}$, remaining grid cells are shown in white. For mean burned area (d), grid cells with no fire occurrence (mean is zero) are shown in white. Trends are shown for all significance levels.

in annual burned area, at least not using the data available to us. While even in the less fire prone regions, fire might play a crucial role in species competition, the direct effect of the smaller relative area of fire scars on the vegetation indices would be limited. NDVI can also be affected by grazing; while any given area might support livestock during most times, the highest pressure on vegetation occurs during longer dry seasons. The negative trends in NDVI and VOD over the South American dry forests are likely caused by deforestation, that is reducing the woody vegetation component and therefore total AGB (Grau et al., 2005).

Trends in VOD occurred in areas of frequent fire, but no coherent spatial pattern was apparent (compare Fig. 7f with Fig. 10b and 10d). Although fire suppresses woody encroachment, dryland fires generally have a relatively low temperature and flame height and therefore do not necessarily affect established woody vegetation (Bond and Keeley, 2005). Woody vegetation increased in the southern African savannas despite recently increased burning (Figs. 10b and 8). This may be explained by increasing precipitation (Fig. 7;
Sankaran et al., 2005), $\mathrm{CO}_{2}$ fertilization (Buitenwerf et al., 2011; Higgins and Scheiter, 2012) and/or grazing by nondomesticated herbivores. A clear increasing NDVI and VOD trend was found for croplands and adjacent grasslands in the USA. Woody encroachment in US grasslands has been widely reported (see Archer et al., 2001, and the references therein) and although there is no straightforward single driver, grazing is understood to play an important role (Van Auken, 2000; Briggs et al., 2005). Increasing agricultural activity could also play a role in explaining those trends (Neigh et al., 2008).

The strongest positive median NDVI and VOD trends were found in agricultural areas (Fig. 9). Increases of both indices over the world's agricultural regions are explained by advances in agricultural practice including mechanization, irrigation and fertilization (Liu et al., 2013a). In India, Pakistan, Bangladesh, China, Ukraine, southwestern Russia, several European countries, the USA, and a number of other countries, substantial areas of agricultural land are irrigated (Wada et al., 2010). Evidence that increasing trends in NDVI are 


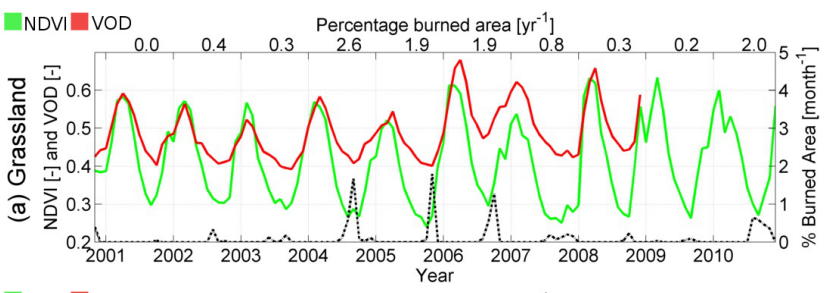

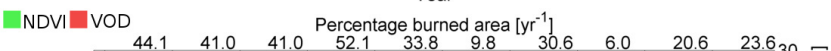

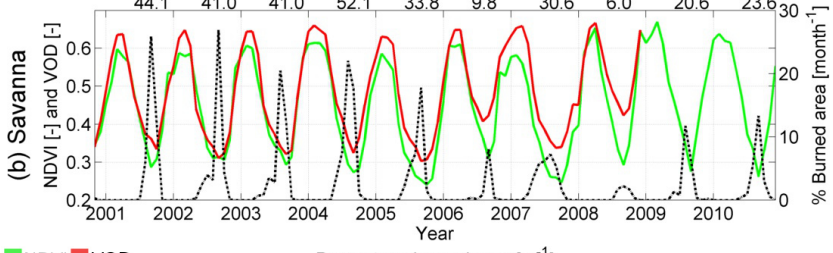

ENDVI $\square$ VOD Percentage burned area $\left[\mathrm{yr}^{-1}\right]$

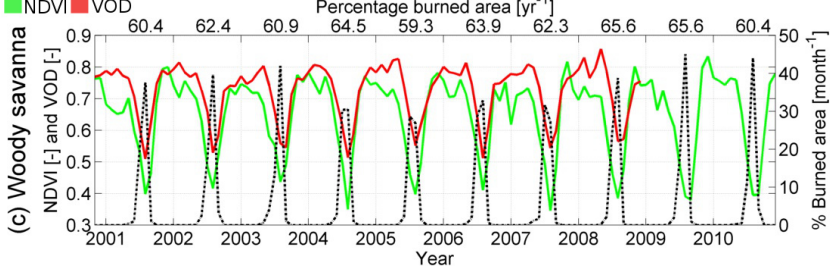

Fig. 11. Time series of NDVI, VOD and burned area (black, dashed) for three selected $0.5^{\circ}$ regions with different land cover in southern Africa: (a) grassland $\left(19.5-20.0^{\circ} \mathrm{S}, 17.0-17.5^{\circ} \mathrm{E}\right)$, (b) savanna $\left(17.0-17.5^{\circ} \mathrm{S}, 17.0-17.5^{\circ} \mathrm{E}\right)$, and (c) woody savanna $(9.5-$ $\left.10.0^{\circ} \mathrm{S}, 19.5-20.0^{\circ} \mathrm{E}\right)$. Numbers above the sub-parts are the percentage burned area $\left[\mathrm{yr}^{-1}\right]$, and locations of study areas are shown as black dots (marked a, b and c) within Fig. 3d.

caused by irrigation and fertilization has been documented for India (Jeyaseelan et al., 2007) and the North China Plain (Piao et al., 2003), while Liu et al. (2013a) showed that positive VOD trends in southern Russia, China, India and the US are the result of increased agricultural production. We used a land cover map of 2005 and for many regions agricultural extent increased during the study period. Therefore, trends may partly be explained by land cover conversion from natural land cover classes to cropland. In drylands at higher latitudes both water and temperature are factors limiting vegetation growth (Nemani et al., 2003), and global changes in temperature can therefore also explain some of the vegetation trends (Tucker et al., 2001).

\section{Conclusions}

A recently developed passive microwave vegetation data set (VOD) and a widely used reflective based vegetation data set (NDVI) were combined to study the long-term (1988-2008) vegetation changes over the world's drylands. We draw the following conclusions:
1. The two data sets provide complementary information on vegetation dynamics; NDVI being most responsive to canopy cover and greenness, and VOD to aboveground biomass.

2. NDVI was more sensitive to herbaceous vegetation changes and short-term precipitation variations. VOD, on the other hand, was more sensitive to changes in woody vegetation and longer-term precipitation variations.

3. Although precipitation is an important driver for dryland vegetation dynamics, precipitation variations could not explain all of the observed trends in vegetation indices.

4. Co-trends between NDVI and VOD provide evidence of widespread woody vegetation encroachment at the expense of the herbaceous vegetation component in arid regions (humidity $<0.3$ ), and arid shrublands in particular. Spatial distribution of trends suggests that a global driver (e.g., $\mathrm{CO}_{2}$ fertilization) is causing a change in relative performance of woody vegetation compared to herbaceous vegetation.

5. Remote sensing evidence for woody thickening and encroachment is also found for some semi-arid drylands, but regional trends vary widely. It is interpreted that local rather than global drivers are responsible for most of the observed residual trends in these areas. Limited observations of monthly burned area suggests that after precipitation, changing fire regimes are an important driver of vegetation change in semi-arid drylands, especially in savannas.

6. Large changes in vegetation density were observed in agricultural dryland regions, where advances in agricultural practices caused increasing trends in both vegetation indices.

In summary, we demonstrated that using two complementary vegetation indices provide new insights into the dynamics of different vegetation components in global drylands. While it remains challenging to conclusively attribute dryland vegetation dynamics to any individual driver, a linear precipitation response model showed that change cannot be attributed to precipitation alone. Global data on fire regimes and grazing enabled a first assessment of the likely relative importance of these drivers on global vegetation change. $\mathrm{Fu}-$ ture improvements and extensions to time series of fire characteristics, grazing and land use change are likely to further improve understanding of global vegetation changes and its drivers. 


\section{Appendix A}

$$
\text { Spearman's rank correlation coefficient }\left(R_{s}\right) \quad \text { Averaging period [months] }
$$
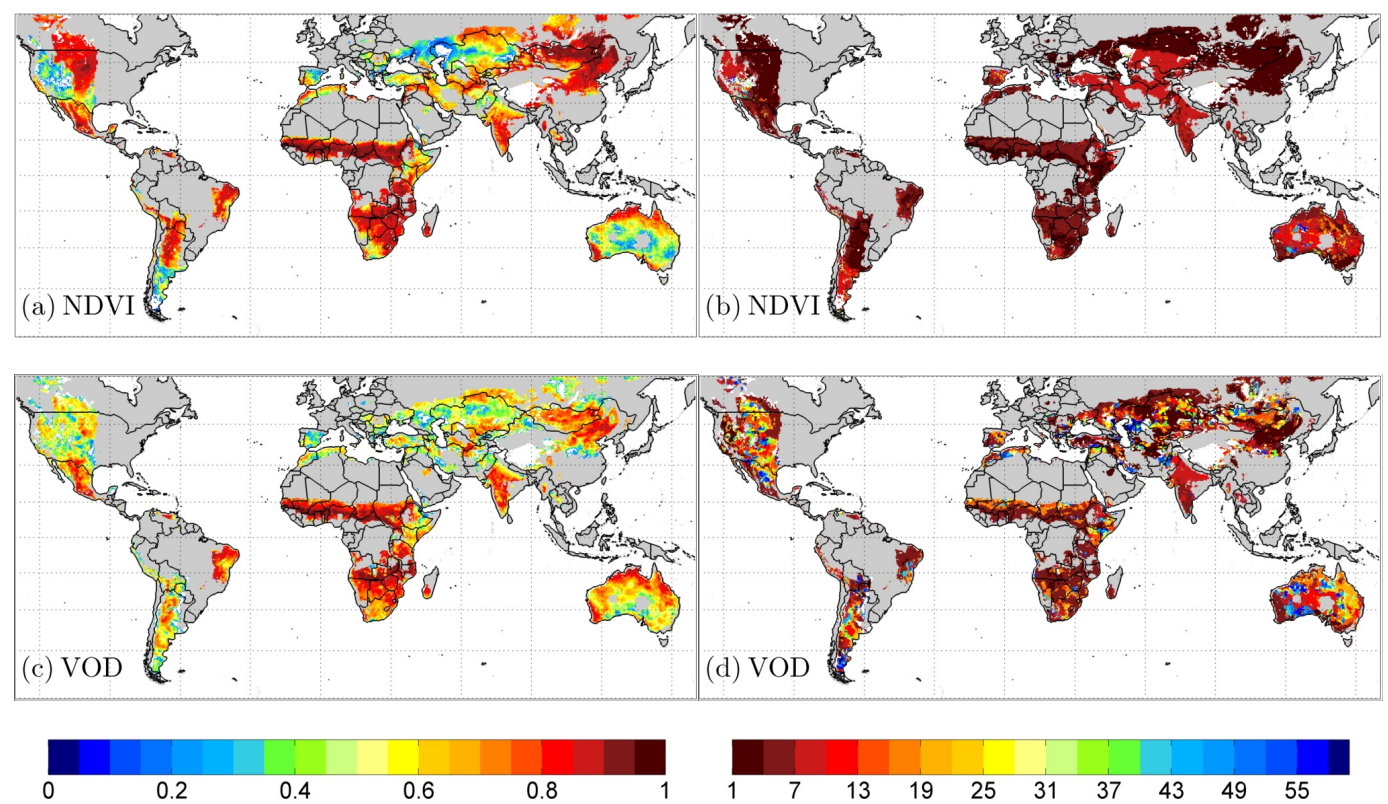

Fig. A1. Spearman's rank correlation coefficient $\left(R_{\mathrm{S}}\right)$ and averaging periods for the two vegetation indices. For the NDVI (a) is the $R_{\mathrm{S}}$ between API and the NDVI and (b) is the averaging period for antecedent precipitation that leads to the highest Rs between PRM and the NDVI, (c) and (d) are as (a) and (b) except for the VOD. Grid cells without significant correlation $(p>0.05)$, with over $60 \%$ missing values, or with a negative correlation coefficients are masked (white).

Acknowledgements. The authors thank Jorge E. Pinzon and C. Jim Tucker (both with NASA, Biospheric Science Branch, Goddard Space Flight Center, Maryland, USA) for providing access to the NDVI GIMMS3g data set (1981-2010).

Edited by: P. Stoy

\section{References}

Adamoli, J., Sennhauser, E., Acero, J. M., and Rescia, A.: Stress and disturbance: vegetation dynamics in the dry Chaco region of Argentina, J. Biogeogr., 17, 491-500, 1990.

Allen, C. D., Macalady, A. K., Chenchouni, H., Bachelet, D., McDowell, N., Vennetier, M., Kitzberger, T., Rigling, A., Breshears, D. D., Hogg, E. H., Gonzalez, P., Fensham, R., Zhang, Z., Castro, J., Demidova, N., Lim, J. H., Allard, G., Running, S. W., Semerci, A., and Cobb, N.: A global overview of drought and heatinduced tree mortality reveals emerging climate change risks for forests, Forest Ecol. Manage., 259, 660-684, 2010.

Anyamba, A. and Tucker, C. J.: Analysis of Sahelian vegetation dynamics using NOAA-AVHRR NDVI data from 1981-2003, J. Arid Environ., 63, 596-614, 2005.

Archer, S., Schimel, D. S., and Holland, E. A.: Mechanisms of shrubland expansion: land use, climate or $\mathrm{CO}_{2}$ ?, Clim. Change, 29, 91-99, 1995.

Archer, S., Boutton, T. W., and Hibbard, K. A.: Trees in grasslands: biogeochemical consequences of woody plant expansion, in: Global Biogeochemical Cycles in the Climate System, 115138, Academic Pres, San Diego, 2001.

Archibald, S. and Scholes, R. J.: Leaf green-up in a semi-arid African savanna-separating tree and grass responses to environmental cues, J. Veg. Sci., 18, 583-594, 2007.

Archibald, S., Roy, D. P., van Wilgen, B. W., and Scholes, R. J.: What limits fire? An examination of drivers of burnt area in Southern Africa, Glob. Change Biol., 15, 613-630, 2009.

Archibald, S., Scholes, R. J., Roy, D. P., Roberts, G., and Boschetti, L.: Southern African fire regimes as revealed by remote sensing, Int. J. Wildland Fire, 19, 861-878, 2010.

Asner, G. P.: Biophysical and biochemical sources of variability in canopy reflectance, Remote Sens. Environ., 64, 234-253, 1998.

Asrar, G., Fuchs, M., Kanemasu, E. T., and Hatfield, J. L.: Estimating absorbed photosynthetic radiation and leaf area index from spectral reflectance in wheat, Agron. J., 76, 300-306, 1984.

Asner, G. P., Borghi, C. E., and Ojeda, R. A.: Desertification in central Argentina: changes in ecosystem carbon and nitrogen from imaging spectroscopy, Ecol. Appl., 13, 629-648, 2003.

Asner, G. P., Elmore, A. J., Olander, L. P., Martin, R. E., and Harris, A. T.: Grazing systems, ecosystem responses, and global change, Annu. Rev. Env. Resour., 29, 261-299, 2004.

Bai, Z. G., Dent, D. L., Olsson, L., and Schaepman, M. E.: Proxy global assessment of land degradation, Soil Use Manage., 24, 223-234, 2008.

Beck, H. E., McVicar, T. R., van Dijk, A. I. J. M., Schellekens, J., de Jeu, R. A. M., and Bruijnzeel, L. A.: Global evaluation of four AVHRR-NDVI data sets: Intercomparison and assessment 
against Landsat imagery, Remote Sens. Environ., 115, 25472563, 2011.

Bond, W. J. and Keeley, J. E.: Fire as a global 'herbivore': the ecology and evolution of flammable ecosystems, Trends Ecol. Evol., 20, 387-394, 2005.

Bond, W. J. and Midgley, G. F.: Carbon dioxide and the uneasy interactions of trees and savannah grasses, Philos. T. R. Soc. B, 367, 601-612, 2012.

Bond, W. J., Midgley, G. F., and Woodward, F. I.: The importance of low atmospheric $\mathrm{CO}_{2}$ and fire in promoting the spread of grasslands and savannas, Glob. Change Biol., 9, 973-982, 2003.

Bond, W. J., Woodward, F. I., and Midgley, G. F.: The global distribution of ecosystems in a world without fire, New Phytol., 165, 525-538, 2005.

Bowman, D. M. J. S., Balch, J. K., Artaxo, P., Bond, W. J., Carlson, J. M., Cochrane, M. A., D’Antonio, C. M., DeFries, R. S., Doyle, J. C., Harrison, S. P., Johnston, F. H., Keeley, J. E., Krawchuk, M. A., Kull, C. A., Marston, J. B., Moritz, M. A., Prentice, I. C., Roos, C. I., Scott, A. C., Swetnam, T. W., Werf, v. d. G. R., and Pyne, S. J.: Fire in the Earth system, Science, 324, 481-484, 2009.

Breshears, D. D.: The grassland-forest continuum: trends in ecosystem properties for woody plant mosaics?, Front. Ecol. Environ., 4, 96-104, 2006.

Briggs, J. M., Knapp, A. K., Blair, J. M., Heisler, J. L., Hoch, G. A., Lett, M. S., and McCarron, J. K.: An ecosystem in transition: causes and consequences of the conversion of mesic grassland to shrubland, BioScience, 55, 243-254, 2005.

Brown, M. E., Pinzón, J. E., Didan, K., Morisette, J. T., and Tucker, C. J.: Evaluation of the consistency of long-term NDVI time series derived from AVHRR, SPOT-Vegetation, SeaWiFS, MODIS, and Landsat ETM+ sensors, IEEE T. Geosci. Remote, 44, 1787-1793, 2006.

Buitenwerf, R., Bond, W. J., Stevens, N., and Trollope, W. S. W.: Increased tree densities in South African savannas: $>50$ years of data suggests $\mathrm{CO}_{2}$ as a driver, Glob. Change Biol., 18, 675-684, 2011.

Carlson, T. N. and Ripley, D. A.: On the relation between NDVI, fractional vegetation cover, and leaf area index, Remote Sens. Environ., 62, 241-252, 1997.

de Jeu, R. A. M.: Retrieval of Land Surface Parameters using Passive Microwave Remote Sensing, Ph.D. thesis, VU University, Amsterdam, 2003.

de Jong, R., de Bruin, S., de Wit, A., Schaepman, M. E., and Dent, D. L.: Analysis of monotonic greening and browning trends from global NDVI time-series, Remote Sens. Environ., 115, 692-702, 2011.

Dorigo, W., de Jeu, R. A. M., Chung, D., Parinussa, R. M., Liu, Y. Y. Wagner, W., and Fernández-Prieto, D.: Evaluating global trends (1988-2010) in harmonized multi-satellite surface soil moisture, Geophys. Res. Lett., 39, L18405, doi:10.1029/2012GL052988, 2012.

Donohue, R. J., McVicar, T. R., and Roderick, M. L.: Climaterelated trends in Australian vegetation cover as inferred from satellite observations, 1981-2006, Glob. Change Biol., 15, 10251039, 2009.

Donohue, R. J., Roderick, M. L., McVicar, T. R., and Farquhar, G. D.: Impact of $\mathrm{CO}_{2}$ fertilisation on maximum foliage cover across the globe's warm, arid environments, Geophys. Res. Lett., 40, 3031-3035, doi:10.1002/grl.50563, 2013.

Dore, M. H. I.: Climate change and changes in global precipitation patterns: What do we know?, Environ. Int., 31, 1167-1181, 2005.

Drake, B. G., Gonzàlez-Meler, M. A., and Long, S. P.: More efficient plants: a consequence of rising atmospheric $\mathrm{CO}_{2}$ ?, Ann. Rev. Plant Biol., 48, 609-639, 1997.

Evans, J. and Geerken, R.: Discrimination between climate and human-induced dryland degradation, J. Arid Environ., 57, 535554, 2004.

Farquhar, G. D.: Carbon dioxide and vegetation, Science, 278, 1411-1411, 1997.

Fensham, R. J., Fairfax, R. J., and Archer, S. R.: Rainfall, land use and woody vegetation cover change in semi-arid Australian savanna, J. Ecol., 93, 596-606, 2005.

Fensholt, R., and Proud, S. R.: Evaluation of Earth Observation based global long term vegetation trends-Comparing GIMMS and MODIS global NDVI time series, Remote Sens. Environ., 119, 131-147, 2012.

Fensholt, R., Langanke, T., Rasmussen, K., Reenberg, A., Prince, S. D., Tucker, C. J., Scholes, R. J., Bao Le, Q., Bondeau, A., Eastman, R., Epstein, H., Gaughan, A. E., Hellden, U., Mbow, C., Olsson, L., Paruelo, J., Schweitzer, C., Seaquist, J., and Wessels, K.: Greenness in semi-arid areas across the globe 1981-2007 an Earth Observing Satellite based analysis of trends and drivers, Remote Sens. Environ., 121, 144-158, 2012.

Flannigan, M. D., Krawchuk, M. A., De Groot, W. J., Wotton, B. M., and Gowman, L. M.: Implications of changing climate for global wildland fire, Int. J. Wildland Fire, 18, 483-507, 2009.

Franks, J. P., Adams, M. A., Amthor, J. S., Barbour, M. M., Berry, J. A., Ellsworth, D. S., Farquhar, G. D., Ghannoum, O., Lloyd, J. McDowell, N., Norby, R. J., Tissue, D. T., and von Caemmerer, S.: Sensitivity of plants to changing atmospheric $\mathrm{CO} 2$ concentration: from the geological past to the next century, New Phytol., 197, 1077-1094, 2013.

Giglio, L., Loboda, T., Roy, D. P., Quayle, B., and Justice, C. O.: An active-fire based burned area mapping algorithm for the MODIS sensor, Remote Sens. Environ., 113, 408-420, 2009.

Gouweleeuw, B. T., van Dijk, A. I. J. M., Guerschman, J. P., Dyce, P., and Owe, M.: Space-based passive microwave soil moisture retrievals and the correction for a dynamic open water fraction, Hydrol. Earth Syst. Sci., 16, 1635-1645, doi:10.5194/hess-161635-2012, 2012.

Grau, H. R., Gasparri, N. I., and Aide, T. M.: Agriculture expansion and deforestation in seasonally dry forests of north-west Argentina, Environ. Conserv., 32, 140-148, 2005.

Hansen, M. C., DeFries, R. S., Townshend, J. R. G., and Sohlberg, R.: Global land cover classification at $1 \mathrm{~km}$ spatial resolution using a classification tree approach, Int. J. Remote Sens., 21, 13311364, 2000.

Heisler, J. L., Briggs, J. M., and Knapp, A. K.: Long-term patterns of shrub expansion in a C4-dominated grassland: fire frequency and the dynamics of shrub cover and abundance, Am. J. Bot., 90, 423-428, 2003.

Herrmann, S. M., Anyamba, A., and Tucker, C. J.: Recent trends in vegetation dynamics in the African Sahel and their relationship to climate, Global Environmental Change Part A, 15, 394-404, 2005. 
Higgins, S. I. and Scheiter, S.: Atmospheric $\mathrm{CO}_{2}$ forces abrupt vegetation shifts locally, but not globally, Nature, 488, 209-212, 2012.

Hijmans, R. J., Cameron, S. E., Parra, J. L., Jones, P. G., and Jarvis, A.: Very high resolution interpolated climate surfaces for global land areas, Int. J. Climatol., 25, 1965-1978, 2005.

House, J. I., Archer, S., Breshears, D. D., and Scholes, R. J.: Conundrums in mixed woody-herbaceous plant systems, J. Biogeogr., 30, 1763-1777, 2003.

Jackson, T. J., Schmugge, T. J., and Wang, J. R.: Passive microwave sensing of soil moisture under vegetation canopies, Water Resour. Res., 18, 1137-1142, 1982.

Jahnke, H. E.: Livestock production systems and livestock development in tropical Africa, Kieler Wissenschaftsverlag Vauk: Kiel, available from: http://pdf.usaid.gov/pdf_docs/pnaan 484 . pdf, 1982.

Jeyaseelan, A. T., Roy, P. S., and Young, S. S.: Persistent changes in NDVI between 1982 and 2003 over India using AVHRR GIMMS (Global Inventory Modeling and Mapping Studies) data, Int. J. Remote Sens., 28, 4927-4946, 2007.

Jones, P. and Harris, I.: CRU Time Series (TS) high resolution gridded datasets, university of East Anglia Research Unit (CRU) NCAS British Atmospheric Data Centre, available from http://badc.nerc.ac.uk/view/badc.nerc.ac.uk_ATOM_ _dataent_1256223773328276, 2008.

Jones, M. O., Jones, L. A., Kimball, J. S., and McDonald, K. C.: Satellite passive microwave remote sensing for monitoring global land surface phenology, Remote Sens. Environ., 115, 1102-1114, 2011.

Jones, M. O., Kimball, J. S., Jones, L. A., and McDonald, K. C.: Satellite passive microwave detection of North America start of season, Remote Sens. Environ., 123, 324-333, 2012.

Kaufman, Y. J., Justice, C. O., Flynn, L. P., Kendall, J. D., Prins, E. M., Giglio, L., Ward, D. E., Menzel, W. P., and Setzer, A. W.: Potential global fire monitoring from EOS-MODIS, J. Geophys. Res., 103, 32 215-32, 1998.

Keenan, T. F., Hollinger, D. Y., Bohrer, G., Dragoni, D., Munger, J. W., Schmid, H. P., and Richardson, A. D.: Increase in forest water-use efficiency as atmospheric carbon dioxide concentrations rise, Nature, 499, 324-327, 2013.

Kirdiashev, K. P., Chukhlantsev, A. A., and Shutko, A. M.: Microwave radiation of the Earth's surface in the presence of vegetation cover, Radio Eng. Electron. P., 24, 37-44, 1979.

Koenig, W. D.: Global patterns of environmental synchrony and the Moran effect, Ecography, 25, 283-288, 2002.

Lehmann, C. E. R., Archibald, S. A., Hoffmann, W. A., and Bond, W. J.: Deciphering the distribution of the savanna biome, New Phytol., 191, 197-209, 2011.

Liu, Y. Y., de Jeu, R. A. M., van Dijk, A. I. J. M., and Owe, M.: TRMM-TMI satellite observed soil moisture and vegetation density (1998-2005) show strong connection with El Niño in eastern Australia, Geophys. Res. Lett., 34, L15401, doi:10.1029/2007GL030311, 2007.

Liu, Y. Y., de Jeu, R. A. M., McCabe, M. F., Evans, J. P., and van Dijk, A. I. J. M.: Global long-term passive microwave satellitebased retrievals of vegetation optical depth, Geophys. Res. Lett., 38, L18402, doi:10.1029/2011GL048684, 2011a.

Liu, Y. Y., Parinussa, R. M., Dorigo, W. A., De Jeu, R. A. M., Wagner, W., van Dijk, A. I. J. M., McCabe, M. F., and Evans, J. P.: De- veloping an improved soil moisture dataset by blending passive and active microwave satellite-based retrievals, Hydrol. Earth Syst. Sci., 15, 425-436, doi:10.5194/hess-15-425-2011, $2011 \mathrm{~b}$.

Liu, Y. Y., Dijk, A. I. J. M., McCabe, M. F., Evans, J. P., and de Jeu, R. A. M.: Global vegetation biomass change (1988-2008) and attribution to environmental and human drivers, Global Ecol. Biogeogr., 22, 692-705, doi:10.1111/geb.12024, $2013 \mathrm{a}$.

Liu, Y. Y., Evans, J. P., McCabe, M. F., de Jeu, R. A. M., van Dijk, A. I. J. M., Dolman, A. J., and Saizen, I.: Changing Climate and Overgrazing Are Decimating Mongolian Steppes, PloS one, 8, e57599, doi:10.1371/journal.pone.0057599, 2013b.

Lu, H., Raupach, M. R., McVicar, T. R., and Barrett, D. J.: Decomposition of vegetation cover into woody and herbaceous components using AVHRR NDVI time series, Remote Sens. Environ., 86, 1-18, 2003.

McMahon, S. M., Parker, G. G., and Miller, D. R.: Evidence for a recent increase in forest growth, P. Natl. Acad. Sci. USA, 107, 3611-3615, 2010.

McVicar, T. R. and Jupp, D. L. B.: The current and potential operational uses of remote sensing to aid decisions on drought exceptional circumstances in Australia: a review, Agr. Syst., 57, 399-468, 1998.

McVicar, T. R., Roderick, M. L., Donohue, R. J., Li, L. T., Van Niel, T. G., Thomas, A., Grieser, J., Jhajharia, D., Himri, Y., Mahowald, N. M., Mescherskaya, A. V., Kruger, A. C., Rehman, S., Dinpashoh, Y., and Rehman, S.: Global review and synthesis of trends in observed terrestrial near-surface wind speeds: Implications for evaporation, J. Hydrol., 416-417, 182-205, 2012.

Meesters, A. G. C. A., De Jeu, R. A. M., and Owe, M.: Analytical derivation of the vegetation optical depth from the microwave polarization difference index, IEEE Geosci. Remote S., 2, 121$123,2005$.

Monsi, M. and Saeki, T.: On the factor light in plant communities and its importance for matter production, Ann. Bot.-London, 95, 549-567, 2005.

NASA: Land Processes Distribute Active Archive Center, MODIS/Terra+Aqua Land Cover Type Yearly L3 Global 0.05Deg CMG V005, US Geological Survey, available from: ftp: //e4ft101.cr.usgs.gov/MOTA/MCD12C1.005/2008.01.01/, 2008.

Neigh, C. S., Tucker, C. J., and Townshend, J. R.: North American vegetation dynamics observed with multi-resolution satellite data, Remote Sens. Environ., 112, 1749-1772, 2008.

Nemani, R. R., Keeling, C. D., Hashimoto, H., Jolly, W. M., Piper, S. C., Tucker, C. J., Myneni, R. B., and Running, S. W.: Climatedriven increases in global terrestrial net primary production from 1982 to 1999, Science, 300, 1560-1563, 2003.

Northup, B. K., Zitzer, S. F., Archer, S., McMurtry, C. R., and Boutton, T. W.: Above-ground biomass and carbon and nitrogen content of woody species in a subtropical thornscrub parkland, J. Arid Environ., 62, 23-43, 2005.

Oldeland, J., Dorigo, W., Wesuls, D., and Jürgens, N.: Mapping bush encroaching species by seasonal differences in hyperspectral imagery, Remote Sens., 2, 1416-1438, 2010.

Ovington, J. D., Haitkamp, D., and Lawrence, D. B.: Plant biomass and productivity of prairie, savanna, oakwood, and maize field ecosystems in central Minnesota, Ecology, 44, 52-63, 1963.

Owe, M., de Jeu, R. A. M., and Walker, J.: A methodology for surface soil moisture and vegetation optical depth retrieval using the 
microwave polarization difference index, IEEE T. Geosci. Remote, 39, 1643-1654, 2001.

Owe, M., de Jeu, R. A. M., and Holmes, T. R. H.: MultiSensor Historical Climatology of Satellite-Derived Global Land Surface Moisture, J. Geophys. Res., 113, F01002, doi:10.1029/2007JF000769, 2008.

Pettorelli, N., Vik, J. O., Mysterud, A., Gaillard, J. M., Tucker, C. J., and Stenseth, N. C.: Using the satellite-derived NDVI to assess ecological responses to environmental change, Trends Ecol. Evol., 20, 503-510, 2005.

Piao, S. L., Fang, J. Y., Zhou, L. M., Guo, Q. H., Henderson, M., Ji, W., Li, Y., and Tao, S.: Interannual variations of monthly and seasonal normalized difference vegetation index (NDVI) in China from 1982 to 1999, J. Geophys. Res., 108, 4401, doi:10.1029/2002JD002848, 2003.

Reich, P. B., Walters, M. B., and Ellsworth, D. S.: From tropics to tundra: global convergence in plant functioning, P. Natl. Acad. Sci. USA, 94, 13730-13734, 1997.

Reich, P. B., Wright, I. J., Cavender-Bares, J., Craine, J. M., Oleksyn, J., Westoby, M., and Walters, M. B.: The evolution of plant functional variation: traits, spectra, and strategies, Int. J. Plant Sci., 164, S143-S164, 2003.

Roberts, D. A., Smith, M. O., and Adams, J. B.: Green vegetation, nonphotosynthetic vegetation, and soils in AVIRIS data, Remote Sens. Environ., 44, 255-269, 1993.

Roberts, D. A., Gardner, M., Church, R., Ustin, S., Scheer, G., and Green, R. O.: Mapping chaparral in the Santa Monica Mountains using multiple endmember spectral mixture models, Remote Sens. Environ., 65, 267-279, 1998.

Robinson, T. P., Franceschini, G., and Wint, W.: The Food and Agriculture Organization's gridded livestock of the world, Veterinaria Italiana, 43, 745-751, 2007.

Roderick, M. L., Berry, S. L., Saunders, A. R., and Noble, I. R.: On the relationship between the composition, morphology and function of leaves, Funct. Ecol., 13, 696-710, 1999a.

Roderick, M. L., Noble, I. R., and Cridland, S. W.: Estimating woody and herbaceous vegetation cover from time series satellite observations, Global Ecol. Biogeogr., 8, 501-508, 1999 b.

Roderick, M. L., Berry, S. L., and Noble, I. R.: A framework for understanding the relationship between environment and vegetation based on the surface area to volume ratio of leaves, Funct. Ecol., 14, 423-437, 2000.

Rossatto, D. R., da Silveira Lobo Sternberg, L., and Franco, A. C.: The partitioning of water uptake between growth forms in a Neotropical savanna: do herbs exploit a third water source niche?, Plant Biol., 15, 84-92, doi:10.1111/j.14388677.2012.00618.x, 2013.

Rouse, J. W., Haas, R. H., Schell, J. A., Deering, D. W., and Harlan, J. C.: Monitoring the vernal advancement of retrogradation of natural vegetation, NASA/GSFC, Tech. rep., Greenbeld, MD, 1974.

Sankaran, M., Hanan, N. P., Scholes, R. J., Ratnam, J., Augustine, D. J., Cade, B. S., Gignoux, J., Higgins, S. I., Le Roux, X., Ludwig, F., Ardo, J., Banyikwa, F., Bronn, A., Bucini, G., Caylor, K. K., Coughenour, M. B., Diouf, A., Ekaya, W., Feral, C. J., February, E. C., Frost, P. H., Hiernayx, P., Hrabar, H., Metzger, K. L., Prins, H. H. T., Ringrose, S., Sea, W., Tews, J., Worden, J., and Zambatis, N.: Determinants of woody cover in African savannas, Nature, 438, 846-849, 2005.
Sankey, J. B., Ravi, S., Wallace, C. S. A., Webb, R. H., and Huxman, T. E.: Quantifying soil surface change in degraded drylands: Shrub encroachment and effects of fire and vegetation removal in a desert grassland, J. Geophys. Res., 117, G02025, doi:10.1029/2012JG002002, 2012.

Sen, P. K.: Estimates of the regression coefficient based on Kendall's tau, Journal of the American Statistical Association, 63, 1379-1389, 1968.

Shi, J., Jackson, T., Tao, J., Du, J., Bindlish, R., Lu, L., and Chen, K. S.: Microwave vegetation indices for short vegetation covers from satellite passive microwave sensor AMSR-E, Remote Sens. Environ., 112, 4285-4300, 2008.

Sternberg, M. and Shoshany, M.: Aboveground biomass allocation and water content relationships in Mediterranean trees and shrubs in two climatological regions in Israel, Plant Ecol., 157, 173-181, 2001.

Theil, H.: A rank-invariant method of linear and polynomial regression analysis, Proceedings of Koninklijke Nederlandse Akademie van Wetenschappen, 53, 386-392, 521-525, 1397$1412,1950$.

Tietjen, B., Jeltsch, F., Zehe, E., Classen, N., Groengroeft, A., Schiffers, K., and Oldeland, J.: Effects of climate change on the coupled dynamics of water and vegetation in drylands, Ecohydrology, 3, 226-237, 2010.

Tottrup, C. and Rasmussen, M. S.: Mapping long-term changes in savannah crop productivity in Senegal through trend analysis of time series of remote sensing data, Agriculture, Ecosyst. Environ., 103, 545-560, 2004.

Tucker, C. J.: Red and photographic infrared linear combinations for monitoring vegetation, Remote Sens. Environ., 8, 127-150, 1979.

Tucker, C. J., Vanpraet, C. L., Sharman, M. J., and Van Ittersum, G.: Satellite remote sensing of total herbaceous biomass production in the Senegalese Sahel: 1980-1984, Remote Sens. Environ., 17, 233-249, 1985.

Tucker, C. J., Slayback, D. A., Pinzon, J. E., Los, S. O., Myneni, R. B., and Taylor, M. G.: Higher northern latitude normalized difference vegetation index and growing season trends from 1982 to 1999, Int. J. Biometeorol., 45, 184-190, 2001.

Tucker, C. J., Pinzon, J. E., Brown, M. E., Slayback, D. A., Pak, E. W., Mahoney, R., Vermote, E. F., and El Saleous, N.: An extended AVHRR 8-km NDVI dataset compatible with MODIS and SPOT vegetation NDVI data, Int. J. Remote Sens., 26, 44854498, 2005.

Van Auken, O. W.: Shrub invasions of North American semiarid grasslands, Annu. Rev. Ecol. Syst., 31, 197-215, 2000.

Vegten, J. A.: Thornbush invasion in a savanna ecosystem in eastern Botswana, Plant Ecol., 56, 3-7, 1984.

Wang, Q., Adiku, S., Tenhunen, J., and Granier, A.: On the relationship of NDVI with leaf area index in a deciduous forest site, Remote Sens. Environ., 94, 244-255, 2005.

Wada, Y., van Beek, L. P. H., van Kempen, C. M., Reckman, J. W. T. M., Vasak, S., and Bierkens, M. F. P.: Global depletion of groundwater resources, Geophys. Res. Lett., 37, L20402, doi:10.1029/2010GL044571, 2010.

Wessels, K. J., Prince, S. D., Malherbe, J., Small, J., Frost, P. E., and VanZyl, D.: Can human-induced land degradation be distinguished from the effects of rainfall variability? A case study in South Africa, J. Arid Environ., 68, 271-297, 2007. 
Wigneron, J. P., Kerr, Y., Chanzy, A., and Jin, Y. Q.: Inversion of surface parameters from passive microwave measurements over a soybean field, Remote Sens. Environ., 46, 61-72, 1993.
Zomer, R. J., Trabucco, A., Bossio, D. A., and Verchot, L. V.: Climate change mitigation: A spatial analysis of global land suitability for clean development mechanism afforestation and reforestation, Agr. Ecosys. Environ., 126, 67-80, 2008. 